Portland State University

PDXScholar

$1-1-1985$

\title{
Subsidized housing for seniors: a comparative study of management styles
}

Thelma Lofquist

Portland State University

Follow this and additional works at: https://pdxscholar.library.pdx.edu/open_access_etds Let us know how access to this document benefits you.

\section{Recommended Citation}

Lofquist, Thelma, "Subsidized housing for seniors: a comparative study of management styles" (1985). Dissertations and Theses. Paper 426.

https://doi.org/10.15760/etd.426

This Dissertation is brought to you for free and open access. It has been accepted for inclusion in Dissertations and Theses by an authorized administrator of PDXScholar. Please contact us if we can make this document more accessible: pdxscholar@pdx.edu. 
SUBSIDIZED HOUSING FOR SENIORS:

\title{
A COMPARATIVE STUDY OF MANAGEMENT STYLES
}

by

THELMA LOFQUIST

A dissertation submitted in partial fulfiliment of the requirements for the degree of

\author{
DOCTOR OF PHILOSOPHY \\ in \\ URBAN STUDIES
}

\author{
Portland State University \\ 1985
}


TO THE OFFICE OF GRADUATE STUDIES AND RESEARCH:

The members of the Committee approve the dissertation of Thelma J. Lofquist presented May 20, 1985.

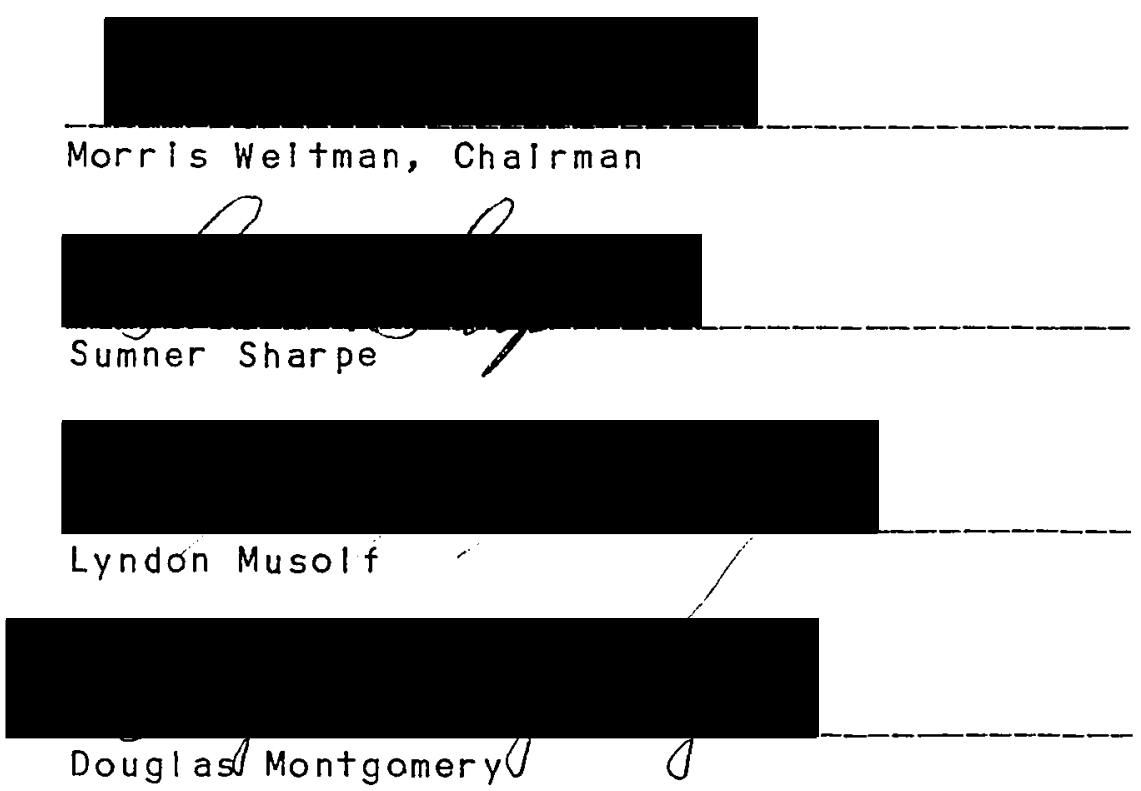

APPROVED:

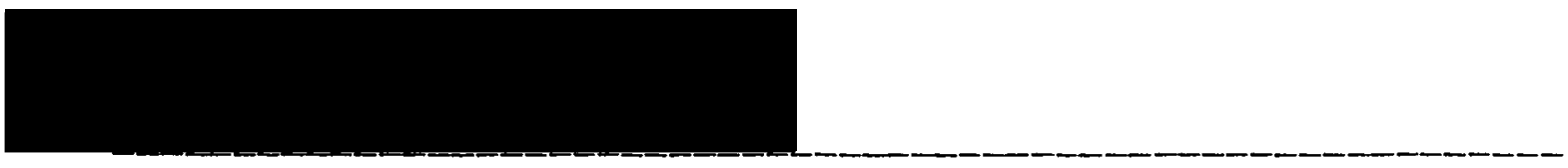

Kenneth Dueker, Acting Dean,

School of Urban and Publ ic Affalrs

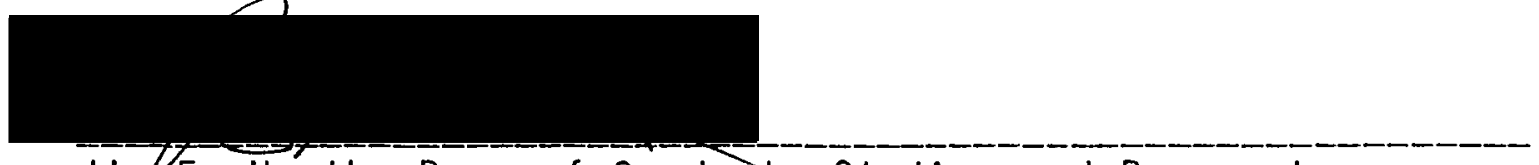

$\operatorname{JimF}$. Heath, Dean of Graduate Studies and Research 


\section{ACKNOWLEDGEMENTS}

I owe a debt of gratitude to the many people who saw this dissertation to completion. I thank my committee members, Dr. Sumner Sharpe, Dr. Lyndon Musolf, and Dr. Douglas Montgomery. Dr. Montgomery so graclously stepped in when a gap in my committee occurred. Special thanks al so to Marllyn Peterson, who agreed to consult on the computer programming, and found herself spending more time than she thought possible; and to my frlends who spent many an evening preparing questionnaire mallings.

A very speclal acknowledgement must go to the chairman of this dissertation committee, Dr. Morris Weltman. Dr. Weltman has gone far and above "beyond the call of duty" In seeling this dissertation to completion. He not only pushed, encouraged, and I istened, Dr. Weltman oversaw all the questionnalre mallings, recelved and cataloged the returned questionnalres, and spent an afternoon in each of the four buildings in this study answering tenants' questions. When push came to shove at the end, he was a rock of Gibraltor. Thank you so very much, Morry.

Loving gratitude goes to my husband, Jerry Lofquist, who has been the mainstay of our family for the many years 1 have been garnering an education. 
TABLE OF CONTENTS

Page

ACKN OWLEDGMENTS . . . . . . . . . . . . . . III

LIST OF TABLES ................. . . . VIII

CHAPTER

I INTRODUCTION ........................... 1

Management Guldellnes....... . 2

Speclal Needs of Older Resldents. . . . 3

Research objectives.......... . 4

II ASSISTED HOUSING PROGRAMS . . . . . . . . 6

Public Housing Authorities. . . . . . 6

Farmers Home Administration . . . . . 8

Section 202 Program......... 9

Section 8 Program.......... 9

III LITERATURE REV IEW ............ . 13

Management of a Problem Project... . 15

PHA Comparison Study . . . . . . . 16

Urban Institute Management

Performance Studies...... 18

University of 111 inols' Resldent

Satisfaction Study ........ 24

Elderly Assisted Housing:

Recommendations Versus Regulations . 27

Research Recommendations . . . . . 28

Management Regulations . . . . . 33 
II LITERATURE REV IEW (CONTINUED)

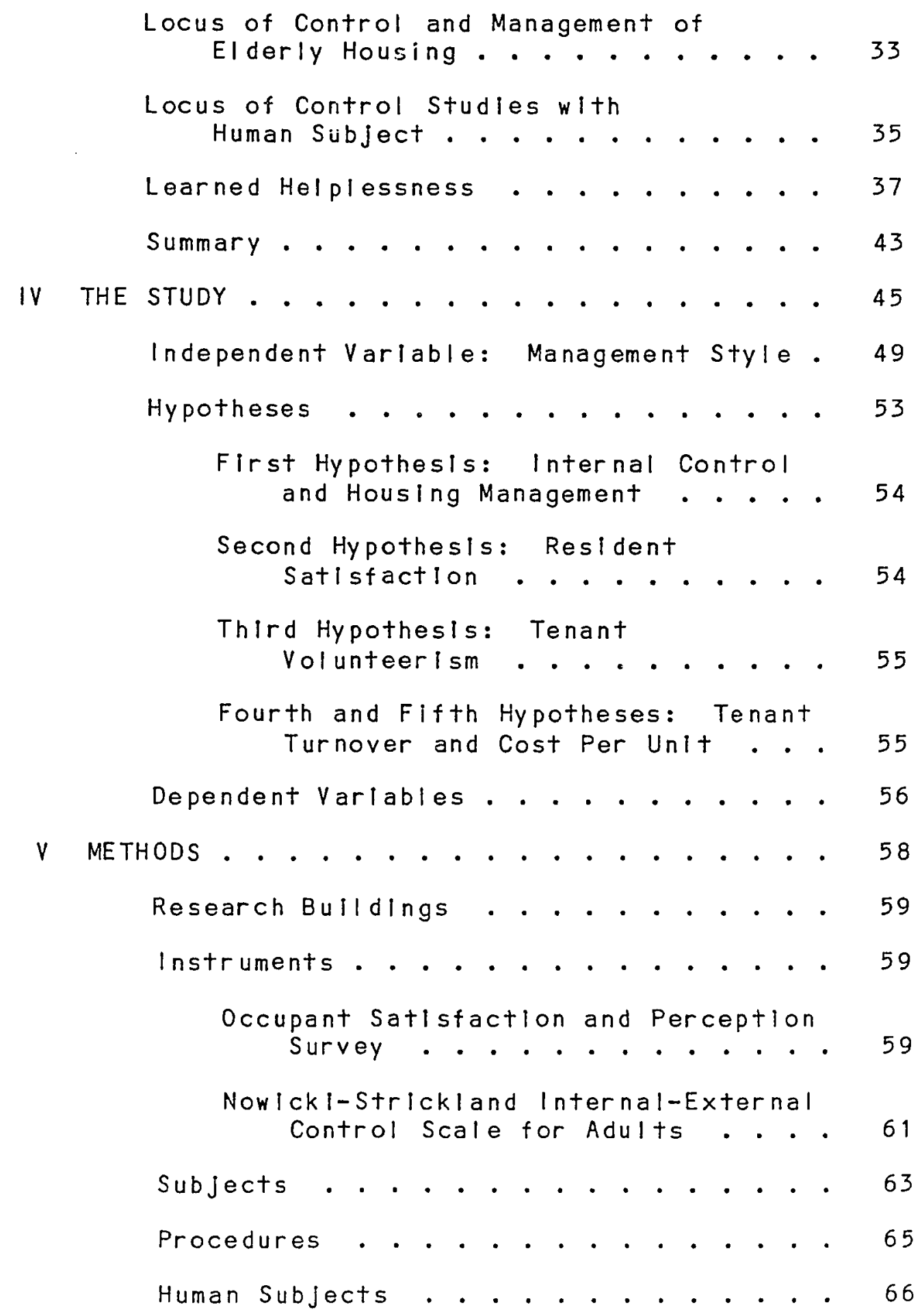


$\checkmark$ METHOOS (CONTINUED)

$$
\begin{aligned}
& \text { Rate of Questionnaire Return . . . . . . . . . . . . . . } 666 \\
& \text { Questionnaire Analysis } 66
\end{aligned}
$$

VI RESULTS . . . . . . . . . . . . . . 68

Locus of Control . . . . . . . . 68

Satisfaction With Management . . . . 69

Volunteerlsm . . . . . . . . . . 70

Tenant Turnover Between Bulldings. . . 71

Cost Per UnIt. . . . . . . . . . . 71

Discussion of Results........ . . 74

First Hypothesis: Internal Versus
External Control...
. . . . 74

Second Hypothesis: Satisfaction
With Management......... 74

Third Hypothesis: Volunteerism. . 75

Fourth Hypothesls: Tenant Turnover. 76

Fifth Hypothesls: Cost Per Unit • . 77

VII CONCLUSIONS AND POL ICY RECOMMENDATIONS • • . 79

Illustrations of Cited Research

Recommendations . . . . . . . . . 79

1. Managers of Senlor Housing

Projects Should Have

Gerontologlcal Tralning... . 79

2. Managers of Senior Housing Should Have Servlce-Referral Skllls . . 80

3. Managers Should know How to Properly Relate to and Communicate With Thelr Older Tenants. . . . . . . . . . 
VII CONCLUSIONS AND POL ICY RECOMMENDATIONS (CONT)

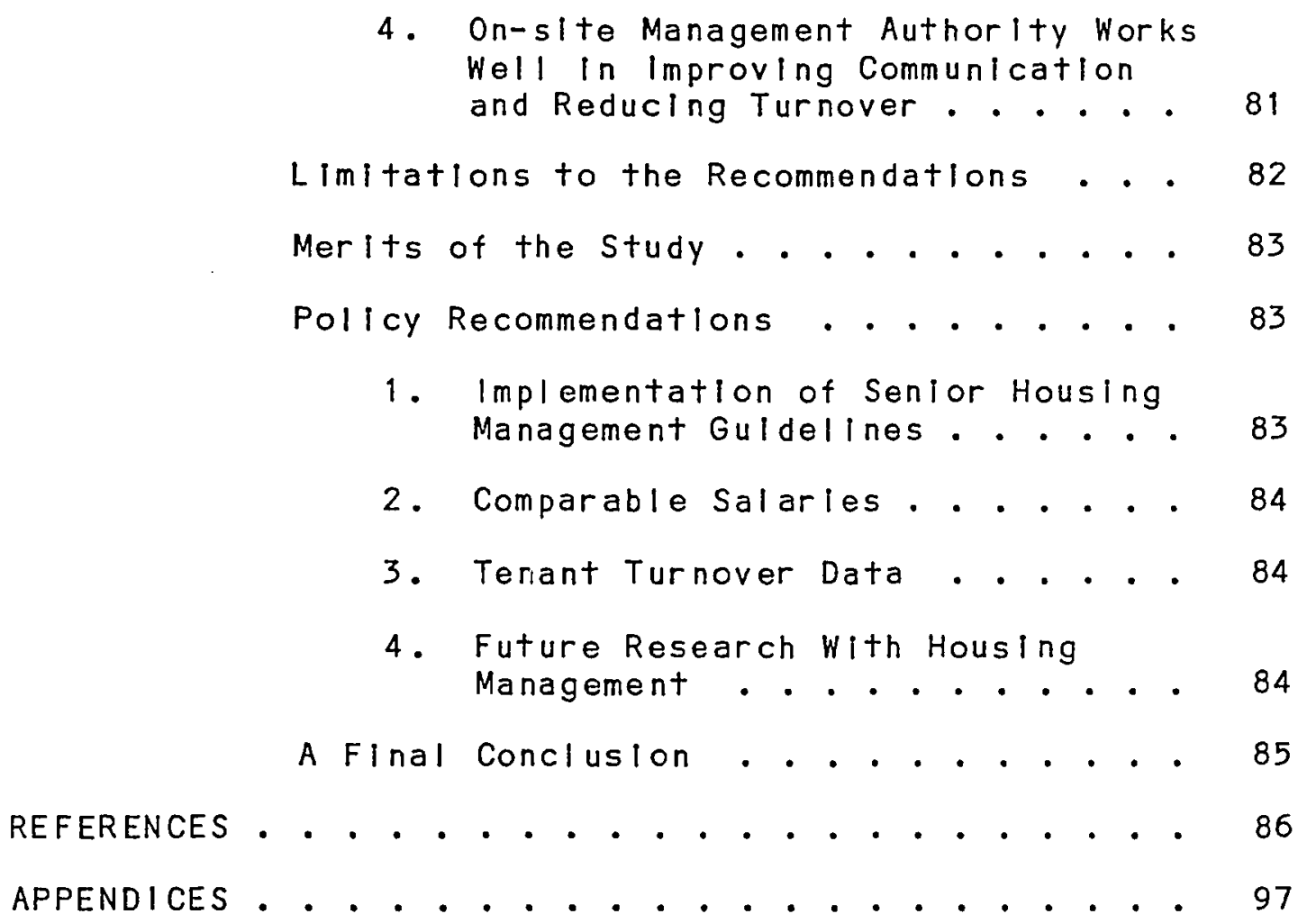




\section{LIST OF TABLES}

Page

TABLE

l Bullding Performance Variables . . . . . . . 23

ll Bullding Descriptions . . . . . . . . . . . . 47

III Independent Varlable: Management Styles . . . . 52

IV Analysis of Varlance of Respondents Who

Completed 32 of the 37 Questions on

the Two-Point ANS-IE Scale . . . . . . 68

$V$ Analysis of Varlance of Respondents Who

Completed At Least Nine of the

Ten-Question Management Scale . . . . . . 69

VI Analysis of Varlance Using Respondents Who

Completed All Items on the Five-Scale,

Five-Polnt Volunteerism Scale....... 70

VII Total Yearly Maintenance Cost Per Unlt Per

Month (April 1, 1983 to March 31, 1984) . . 73 
AN ABSTRACT OF THE DISSERTATION OF Thelma J. Lofquist for the Doctor of Philosophy in Urban Studles presented May 20, 1985.

Title: Subsldized Housing for Seniors: A Comparative Study of Management styles.

APPROVED BY MEMBERS OF THE DISSERTATION COMMITTEE:

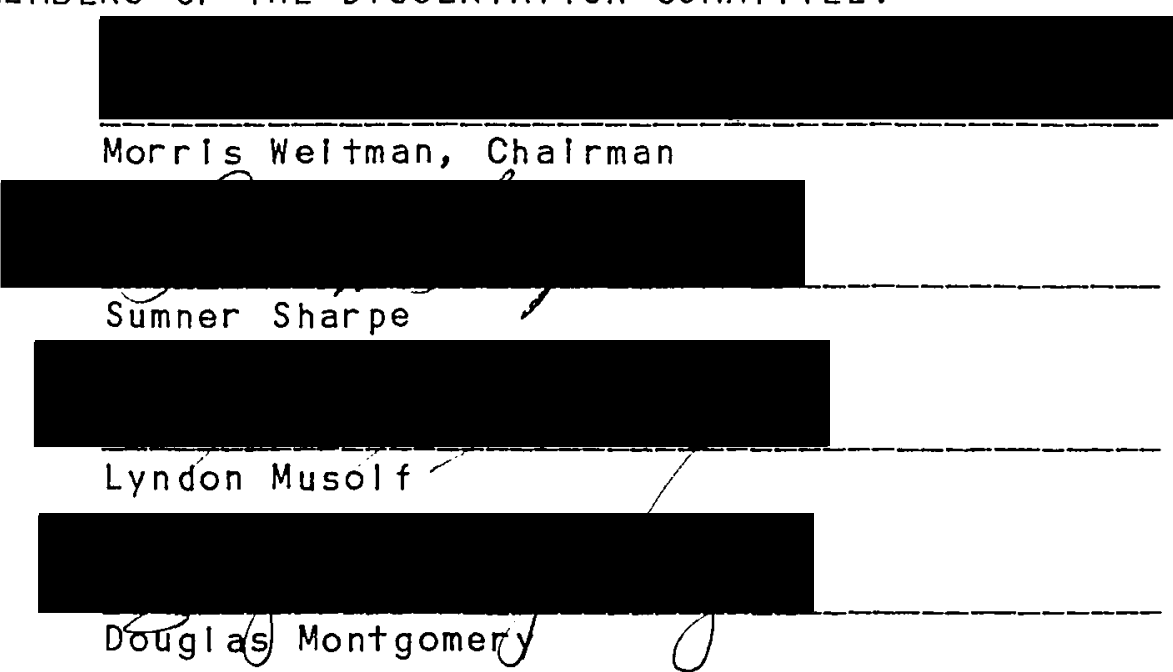

Studies conducted at the Urban Institute in washington, D.C., during the 1970 's, defined a management style already existing for high-performance, assisted housing primarlly for fam llies.

Project performance in those studies was based in part on: (a) tenant satisfaction with management, (b) tenant turnover rates, (c) rent del inquency rates, (d) vandal ism rates, and (e) operating cost per unit. 
For this dissertation an attempt was made to evaluato the use of high-performance management guldellnes with a newly opened, assisted-housing project for elderly and handicapped residents.

The guldel Ines used for this study were (a) authorlty for the project was based on-site, (b) malntenance responsibilities were based on-site, (c) management was a source of service-referral.

The Bullding, Building $A$, was compared to three existing similar projects where management authorlty differed. Cost comparisons were made from malntenance budgets from the four buildings. Comparisons of tenant satisfaction with management, volunteerism rates, and perceptions of locus of control were made by means of a questionnalre malled to all tenants in the four bulldings.

A locus of control scale was included with the management study because of the special needs of aging residents who face uncontrollable losses in the later years. There is a body of llterature that indicates that offering institutionalized senlors some small environmental control has a positive impact on their behavior.

Whlle the residents in this study are not institutionalized, it was thought that the management style of the experimental bullding, where authority for the project was based on-site, might influence tenant perception of locus of control. 
Responses to the questionnalres did not support the hypothesis that residents In Bullding A would have signiflcantly higher perceptions of (a) internal control, (b) satisfaction with management, (c) volunteerlsm rates. There was support for the hypothesis that maintenance operating costs for Bullding A would be significantly lower when comparisons were made among the four bulldings.

The study concludes that (a) management research would benefit by developing methods to better deflne and measure management behaviors, (b) data on the reasons for tenant turnover are important sources of information not presently beling utilized in senior-projects experiencing vacancy problems, (c) the results of the operating maintenance costs comparisons in this study reinforce the Urban Institute's management guidelines as a polnt for serlous consideration by developers of assisted-housing for elderly and handlcapped tenants. 


\section{CHAPTER 1}

\section{INTRODUCT ION}

Federally-assisted housing has a long history of operational problems, and many projects over the past 20 years have been faced with operating deficlts and defaults (Pollkoff, 1978; Sadacca, Isler, and Carlson, 1976; Stegman, 1980; Struyk, 1980).

Now, during the 1980's, federally assisted housing, whether under the sponsorship of Public Housing Authorities (PHAs), private nonprofit sponsors or private developers, is facing major funding cutbacks (Astorino, 1981; Howell, 1984; Meehan, 1983; Nenno, 1982; Ostrowski, 1984; Struyk, Mayer \& Tucillo, 1983).

Joseph Howell (1984), in an article entitled, "Project Syndication--How It Works," states: "In the 1980's housing is not a prlority under the present Admlnistration. The Federal Government has sent the message loud and clear, fInd new and creative solutions to your problems, involve the private sector, be more efficlent and businesslike."

These problems, along with growing evidence of a vacancy problem in assisted-housing projects for elderly in some areas of the country (simmons, 1984; Wolfe, 1984), prompted the design of this present research (Appendix A). 
The intent was to use management research guldelines from earlier studies to administer an assisted-housing project for elderly and handlcapped residents, and compare these management technlques with more traditional management practlces employed in three simllar projects.

\section{Magnagement Guldellnes}

The operating problems of assisted-housing sponsors prompted the U.S. Department of Housing \& Urban Development (HUD), the federal agency that adminlsters metropolitan housing programs, to fund a series of studies during the 1970 's to investigate the financlal problems of assisted housing.

Research conducted durling that period by the Urban Institute of Washington, D.C. indicated that on-site, firm, falr, responsive management practices resulted in fewer rent delinquencles, lower tenant turnover, less vandal ism, and higher tenant satisfaction when compared with assisted proJects overal) (Isler, Sadacca \& Drury, 1974; Sadacca \& Loux, 1978; Sadacca, Carlson \& Loux, 1978).

This firm, falr, responsive management style, with authorlty based at the project level is examined in this present research study in the context of cost benefits and tenant satisfaction in assisted housing designed for elderly and handicapped residents. 


\section{Speclal_Needs of Older Residents}

As people age, they are faced with a serles of losses, be they mental, economlc, or personal (Hooker, 1976). For those seniors who must move to assisted housing for economic reasons, the loss of possessions, space, nelghbors, and nelghborhood can be traumatic (Fitzgerald, 1979; Lawton, 1975).

Some responses to these losses can be depression, alcoholism, chronic complaining, unreasonable demands for services, neglected units, paranoia, confusion, and even sulclde (Lawton, 1975). Because of these losses, it seemed approprlate to introduce a second area into this present study and to explore the posslbllity of a relationship between management practices in assisted housing for senlors and the tenants' perceptions of control of their environment. A small body of research with institutionalized elderly Indicates some positive aspects for resldents who were given control over seemingly minute facets of their environment (Brandt, 1979; Mercer \& Kane, 1979; Reld, Haas \& Hawkings, 1977; Wolk, 1976).

With the Urban Institute guidelines for successful housing management, firm management is baslcally the estabI Ishment of necessary regulations, so that tenants are aware of the rules, and firm and fair enforcement of regulations takes place (Sadacca et al., 1976). Awareness of building 
regulations and expectations that management will be firm in enforcement creates a climate of predictabllity, an important element in locus of control theorles. Herbert Lefcourt (1976) In Lecus of Control, states:

If another person is predictable, then we have a good idea of how one must act with him to cause certaln effects... predictabllity allows us some sense of confldence that we can act to create desirable effects.

On-site management allows tenants to know "who to go tol for information or requests. Authority at the project level allows management to respond both approprlately and effectively to tenant requests, giving older tenants "some sense of confidence that they can act to create desirable effects" (Lefcourte, 1976).

\section{Besearch_objectives}

Thls study brought a "firm, falr, responsive management style" into practice at a newly opened project for elderly and handicapped residents. The results, both tenant perceptions of management and building operations, were compared with three similar projects.

In the light of past operating deficits, present budget cuts in assisted housing, and possible vacancy problems developing in retirement housing, this work takes on a more important plcture in light of the need for efficlent management practices in the 1980's. 
Because of the speclal needs of elderly residents, tenant perceptions of internal control in relation with the management style of the four bulldings were also measured. 
CHAPTER II

\section{ASSISTED HOUSING PROGRAMS}

This country entered the assisted-housing business in 1937 with the enactment of the United States Housing Act. Spawned by the depression of the 1930's, the Act was Intended to alleviate unemployment and provide "decent, safe, sanltary" housing for the unemployed who were expected to use housing assistance on a temporary basis (Zals, Struyk and Thlbodean, 1982).

\section{Public Housing Authorlties}

In the late 1930's Public Housing Authorlties (PHAs) were established to develop, operate, and malntain assisted housing in metropolitan areas. In the mid 1950's, the federal government encouraged traditional programs through the Department of Housing and Urban Development (HUD).

During the early years of PHA programs, while the federal government provided the development funds, the PHAs were expected to meet operating expenses from rents and utllity charges. Local governments supported PHA developments by not levying taxes agalnst them and by provioing service amenities such as police and fire protection. PHAs had the right of "em inent domain" under the sponsorship of 
the federal government, glving them powers of a minigovernment. However, local governments malntained direct control by appolnting boards of commlssloners to oversee the management of the Authorities and through the enforcement of local bullding codes (National Housing Law Project, 1982; Struyk et al., 1983).

PHAs set rental amounts and tenant income limits. However, after early development years, operating costs escalated and older projects began to need rehablilitation.

To compound the problem, the federal pollcy after the Second World War sought to provide housing for veterans and the working middle class through tax breaks and guaranteed home loans. This created a "fllght to the suburbs," so that publlc housing became the housing source for very low Income, unemployed, or welfare recipients who viewed public housing as permanent housing. In the 1960's, tenants in public housing were in the tenth percentlle of income distribution overall (Welcher, 1980).

PHAs attempted to ralse rents to meet operating costs, putting rental amounts out of the reach of very low income tenants. Because of tenant inabllity to meet PHA rents and PHAs' Inabllities to meet operating costs, Congress passed the Brooke Amendment in 1969. The Amendment set rent IImits for PHA tenants which were not to exceed 25\% of their Income, and provided operating subsidies to the PHAs. HUD used the subsldy granted by the Brooke Amendment to cover 
PHA operating deficits and to help PHAs malntain financial reserves (Cartee, 1981; Liston, 1974; NAHRO Blbl lography, 1984; National Housing Law Project, 1982; Struyk et al., 1983).

Since these HUD operating subsidies rewarded Inefficlent PHAs, federal costs began to balloon to such large proportions that a performance funding system was Implemented in 1974. The performance funding system IInked the PHA's actual operating costs to a performance standard defined by HUD. Al though this system continues today, it has not prevented some PHAs from falling into severe operating deficiencies (Struyk, 1980).

Whlle other varlations of housing assistance programs have been inltiated over the years, the major programs impact the most a community's assisted housing. These Include: the PHA conventional housing program, the federal Farmers Home Administration program, and HUD's Section 202 and Section 8 programs which give assistance under the sponsorshlp of nonprofit owners and private developers.

\section{Earmers_Home_Administration}

In 1949 the Farmers Home AdmInistration (FHA) was InItiated to provide assisted-housing programs for small communities and rural areas. The FHA differs from HUD in that FHA programs are under the jurlsdiction of the 
Secretary of Agrlculture, and local state and county agencles, rather than PHAs, administer the programs. The state director targets FHA resources to particular areas and persons, and county offlces administer both multi-famliy housing and community development programs (National Law Project, 1982).

\section{Section_202 Program}

The Section 202 Program was instituted In 1959 to provide federal loans to private, nonprofit sponsors to develop, operate, and malntain projects for elderly and handlcapped residents. The nonprofit sponsors were expected to provide service amenities to their residents and to reserve at least $20 \%$ of their units for the very low income elderly (U.S. Department of Housing \& Urban Development, 1984; Natlonal Houslng Law Project, 1982; Zals et al., 1982). It is now thought that since Section 202 projects recelve rent subsidies through the section 8 Program, that a high percentage of their tenants fall into the low income range (Zais et al., 1982).

\section{Sectlen 8 Program}

The Section 8 Program, enacted in 1974, falls into four categorles: Section 8 Certificate, Moderate Rehabilitation, Substantial Rehabilitation, and New Construction. 
The certificate program is administered through local PHAs. Eligible tenants first apply for certificates and then locate units from landlords in the private sector who are wllling to participate in the program. Units must meet both the PHA's rental amount || $\mathrm{mltat}$ ions and structural guidelines. Tenants pay their portion of the rent, which is dictated by their income. The landlord then collects the rest of the rental amount from the PHA. A unit's condition is monitored by the PHA to ensure that the housing stays structurally sound.

The Rehabliltation/New Construction phase of Section 8 allows a private developer to recelve a subsidy on units in projects that were rehabilitated or constructed through loans from private lenders or state-lending agencles. HUD sets a fair market value on the units based on the local market and the developer's loan costs. The owner/developer operates and maintains the project and receives the falr market rent for each unit from a combination of the tenant's share and the Section 8 federal subsldy (U.S. Department of Housing \& Urban Development, 1984; National Housing Law Project, 1982; Sloan, 1984; Struyk, Marshall and Ozanne, 1978, Zals et al., 1982).

Whlle Section 8 Rehabilitation/New Construction subsldy funds have been avallable for both multi-famlly and elderly and handlcapped projects, $54 \%$ of the development has 
been in the area of elderly housing (Warner, 1983). Owners and developers often prefer the development of elderly housing over multi-family projects, because management of housing for sentors is viewed as less problematic than projects for famllies (Francescato et al., 1979; National Housing Law Project, 1982).

However, since the 1980 budget cuts, no new funds have been allocated for the Section 8 Rehabliltation/New Construction programs and only a limlted amount of funding for Section 202 projects for elderly and handicapped residents remains. There is speculation that HUD's future emphasis will be on housing vouchers exclusively (Meehan, 1983).

Housing vouchers are similar to Section 8 certificates as eliglble tenants are able to locate their housing in the open market. The vouchers differ from the Section 8 certificate program because the distrlbuting agency, normally a local PHA, has less involvement. With the Section 8 certiflcates, the PHA assigns the certiflcate to the tenant, the tenant locates a sultable unit, and the PHA monitors both the landlord and the unit, often with fairly stringent requirements. The relationship is between agency and tenant, and agency and landlord. WIth the housing vouchers, the relationship is between tenant and landlord, with the agency's prime role being the distribution of the voucher (Z a)s, 1984). 
With PHA projects, Section 8 Rehabliltation/New Construction, and section 202 projects, the unit itself is subsidized. With section 8 certificates and housing vouchers, the tenant is subsidized.

HUD appears to place a strong emphasis on the voucher program in 1985 and has halted further development of new bulldings. For existing subsidized housing, operating assistance has been curtalled, and badly deterlorated housing projects are expected to be destroyed rather than rehabilitated (Friedman \& Welnberg, 1982; Galner, 1983; Meehan, 1983; Nenno, 1982; Ostrowskl, 1984; SIoan, 1984; Struyk et al., 1983; Zals et al., 1982). 
CHAPTER 111

\section{LITERATURE REV IEW}

Management of assisted housing is generally consldered to be more difflcult than management of housing in the private sector Conrad, 1970; Fitzgerald, 1977; French, 1977; Matheny, 1976; Murray, 1972a, 1972b; Simmons \& Watson, 1973; Stegman, 1980; Wollock, 1977). While location and project construction are sometimes cited as part of managements' problems and are often used as reasons for not improving management practices (Struyk, 1980), "people problems" are considered the major management challenge (Conrad, 1970; French, 1977). Glen French, Director of Management for the Cambridge Housing Authority, finds that "people problems demand more than normal management expertise. . they are most times given as reasons for a project's fallure."

People problems cited include poverty tenants who lack education, motivation, respect for other's property, and who encourage destruction and vandallsm (French, 1977).

Joseph Conrad (1970) in "Getting Involved in Low Income Housing," discusses the people problems that confront managers. He finds that the many soclal problems in assisted housing can be handled by a "well trained mana- 
ger. Who knows that attitudes play a dominant role in management relations." Conrad does not say it is easy: "Managers of subsidized housing must go a step beyond the norm." His criterla are that the "tenant be treated with respect as an adult and that managers themselves be responsive to tenant needs."

In "Reducing the Risks of Subsidized Housing," Gien French (1977) defines management as, "the ever existing condition in which all residents are aware the management assumes its responsibllity fully and wlll insist upon lease compliance firmly, yet falrly."

Robert Fitzgerald (1977) In his article, "The Public Housing Manager, No Place for a Loner," states:

The tenants don't belong to you, or to anything or anyone. Their personal freedom is their most sacred possession in the same sense that all citizens regard it as both a rlght and a responsibllity... reacting to tenants as people will be a concern, a constant interest, and a source of many personal satisfactions.

In the "Turnaround Handbook for Problem Properties," Richard Wollock (1977) stresses tenant relations. He says tenants must be told of management goals for a complex and suggests seeking their cooperation. He says, "psychologlcally everyone wants to believe that he lives in a good environment and made a wise decision when choosing this complex." He claims management firmness creates a positive mental attitude among residents, and when disruptive tenants 
create discontentment among good tenants, they must be dealt with firmly, even to the polnt of eviction.

Evictions are a necessary part of management of assisted housing. J. S. Fuerst (1977) in hls article, "Subsldized Houslng: Amateurs Need Not Apply," demonstrates how a problem project can be turned around by evicting both non-rent paying families and tenants who disturb others. He says the use of eviction can help keep a project occupled, solvent, and integrated. A more important varlable than eviction, however, is careful tenant selection. He teels that with careful screening and credit checks, evictions can become minimal.

\section{Management of a_Problem_Project}

In 1974 during a bitter tenant strike, Carmen Porco (unpublished manuscript, 1980) took over management of a 250-unit, subsldized famlly housing complex in Madison, wisconsin. The complex was plagued by vandalism, high vacancy rates, and high tenant turnover. Mr. Porco reversed these problems over a perlod of one year, reducing the vacancy rate from $45 \%$ to $1 \%$, the rent delinquency rate from $22 \%$ to $0 \%$, yearly turnover rate from $31 \%$ to $6 \%$, and maintenance complaints from 190 to 60 per month (Ihe lregendan, 1980).

Carmen Porco relled heavily on a lengthy tenant orientation process. Before a lease was slgned, "lease and 
management pollcles were explalned in detall.. not only tenant's obligations but management's obligations as well." The manager explalned staff working hours and staff duties, how complaints were handled and how problems could be avolded. Porco says:

Explaining everything to the tenants without relying on stone-wall and fear tactics makes them more likely to keep the buildings and grounds in good condition, and they do much of the cleanup and fixup tasks themselves (Ihe Qregenlan, 1980).

In $1979 \mathrm{Mr}$. Porco took over a second large famliy project accomplishing similar results in less than a year. Since that time, Carmen Porco has become a full-time consultant to the Madison, Wisconsin Public Housing Authority, again successfully implementing his management policies throughout the entire PHA system in Madison, Wisconsin. Baslcally, Carmen Porco's approach to project management is:

i. A lengthy or ientation and introduction process to the complex.

2. Keeping tenants well informed and relating to them on an adult-to-adult basis.

\section{PHA Comparison_study}

A study of 15 housing projects in three Canadian cities by Adipoju Onibokun (1974) Indicates again how management attitude and performance affect tenant satisfaction and project costs. 
Two models of management were ldentifled as a result of the study:

1. The paternal and unresponsive model.

2. The empathetic and unofficlous model.

The paternal Ist model had author itarlan management that was unresponsive to tenants' complaints. The tenants stated they felt "no self worth, dignity, or pride." The paternal management model fostered open conflict in one city, compounding management problems.

Onibokun's emphathetic and unofficlous model is simllar to Porco's (1980) approach with a positive orlentation process and positive attitude relating to tenants:

When a new tenant is admitted, the manager takes her to the housling project, shows her her own housing unlt, hands her the key and says, "Well, this is your house; regard it as your own personal house, and take care of it as you would your own property." The Authority addresses the tenants polltely and even when the tenants do some wrong, the response of the Authority is not harsh and dictatorial. When there is need for repalrs within the housing units, the management acts promptly and ensures that the repalrs are done to the satistaction of the tenants. Some of the tenants in the housing projects had repainted their housing units themselves and the paint in such cases was supplied by the Housing Authority and this approach ylelded positive results. Tenants' complaints about renovation and housing repair were noted to be very negligible in most of the housing projects under the jurlsdiction of this Housing Authorlty.

in enforcing the rules, the management has actively involved the tenants themselves, and they assume a greater part of the responsibllity of identifying which rules are necessary and that the rules are adhered to. 
The results have been very gratifying. Complaints about management are found to be relatively few. A great majority or the tenants have a feelling of self-worth, responsibli ity and self-respect (Onibokun, 1974).

In this three-city study of 15 housing projects, the attitude of the PHAs toward their tenants affected management policles and had a declded effect on the livability of projects. Well-built bulldings with spaclous apartments had their "I ivablilty impaired by management who disregarded tenants' feelings." Tenants had poor relations with what Onlbokun calls "authoritarian housing authorlties." $\mathrm{He}$ found management differs from city to city in publlc housing and feels that poor management does a great disservice to the cause of assisted housing nationally. He found great contrasts in management, and in those PHAs where "good management" or what he calls "empathetic and unofficlous management" prevailed, there were economic benefits (Onibokun, 1974).

\section{Urban Instltute Management Performance Studies}

HUD-funded studies during the 1970's investigating the financial problems of assisted housing found numerous factors leading to deficlts and defaults:

1. The building in the 1950's and 1960's of mammoth housing projects in high crime areas. 
2. Construction of projects as spartan as possible without recreational faclilties or other amenitles needed for the large number of people housed.

3. Projects deterlorating to a polnt where maintenance and repair costs became overwhelming.

4. Poor management practices.

(Polikoff, 1978; Struyk, 1980; Wye, Plokering \& Kaninsk, 1980)

Cost efficient administration of such large, deteriorating projects where tenants are resentful of their environment, management, or both, is extremely difficult at best and Impossible at worst. However, Raymond Struyk, Director of the Center for International Activities of the Urban Institute of Washington, D.C., In his analysis of public housing (1980), finds that density, size, and location are often excuses used to prevent implementing better management practices. His analysis is based, in part, on HUD-funded research at the Urban Institute.

Beginning in 1971, the Urban Institute began a 9-year serles of research studies into the financial problems of assisted housing. During the course of that research, over 21,000 interviews were conducted and 460 projects were studied. Sixty of the projects were under private developers, nonproflt or cooperative ownershlp. Four hundred of the projects were owned by PHAs. Two-thirds of the interviews were with tenants and the last third with PHA 
and project staff (Isler, Sadacca \& Drury, 1974; Sadacca \& Loux, 1978; Struyk, 1980).

Four baslc categories were developed from the interviews and other data sources, such as vacancy rates and rent delinquencies. The four categorles were:

1. Criterion measures which assessed the overall management performance of a PHA.

2. Control measures which described area, neighborhood, project and tenant characteristics over whlch the PHA had no control.

3. Management measures which described management pollicles, practices, and the attitudes of tenants and PHA staff.

4. Income and expense measures which were related to operating Income and expenses of PHAs.

Measures were developed from the categorles and adjusted to take into account operating conditions over which the PHA had no control, such as older buildings in poorer nelghborhoods, and used to divide PHAs into high- and low-performance groups. High- and low-performance PHAs had complexes that performed accordingly, and in hlghperformance complexes, there was low tenant turnover, low vandallsm and vacancy rates, high resident satisfaction and fewer complaints. Low-performing complexes had operating 
losses, rent delinquencles and rental losses, high vandallsm rates, and lower Fenant satisfaction.

In high-performance bulldings project managers had more authority, were firm in enforcing rules and evicting problem tenants, and were responslve to tenant needs and concerns. Tenants in these complexes were less inclined to particlpate in formal tenant organizations, but participated on an informal, day-to-day basis. Tenants formed more formal organizations in those complexes where management was felt to be inadequate in some way.

Varlables Identifled from Urban Institute studies that Impacted on bullding performance were:

Uncontrollable Varlables:

1. Neighborhoods

2. Age of building

3. Elderly vs. family bulldings

Controllable Varlables:

1. Attitude of staff toward their work and toward each other

2. Decentralization of authority to the project |evel

3. Management firmness

4. Management responsiveness

5. Tenant roles, including cooperativeness, project cohesiveness, and tenant involvement in the building. 
A comparison of bullding performance as defined in the Urban Institute studies is III ustrated in Table I (Sadacca, Loux \& Carlson, 1978).

Management firmness is defined as enforcling rules strlctly and fairly. Nolse levels are kept at a tolerable level, and tenants keep the grounds clean. Management takes less time to evict tenants for rent delinquency and wIII evict for poor behavior, l.e., drunkenness, berating of other tenants.

Management is considered responsive when:

1. Tenants feel they are treated well by staft.

2. Tenants feel the manager knows a good deal about the job.

3. Malntenance problems are taken care of promptly.

4. Complaints are responded to promptly.

5. Repalrs are made promptly.

6. Managers know tenants by name and by sight.

7. The manager is a source of service information.

8. Tenants know who to contact for emergencies.

(Loux \& Sadacca, 1975; Sadacca et al., 1976; Sadacca, Loux \& Carlson, 1978)

The Urban Institute study was the first comprehensive management focused research conducted nationwide on assisted housing. The study assumed the relative importance of 
TABLE 1

BUILDING PERFORMANCE VARIABLES

1. Tenants percelve nelghborhood as improving.

2. New buildings.

3. Elderly population easler to manage.

4. Positive attitude of staff toward their jobs, tenants and each other.

5. Authority central ized to each project.

6. Management firm in keeping nolse down, less time to evlct tenants for rent delinquencles or disruptive behavior.

7. Management responds quickly to maintenance complaints, treats tenants with respect, knows tenants by name, is avallable.

Tenants know who to contact for problems.

8. Tenants volunteer in and around building, active in bullding activities. Tenants less I ikely to want to particlpate in management.
1. Tenants percelve nelghborhood as deterlorating.

2. Very old bulldings.

3. Multi-famlly bulldings more difficult to manage.

4. Negative attitude of staff toward their jobs, tenants and each other.

5. Authority in central office.

6. Management not quick to stop disruptive behavlor, less likely to evict disruptive or del inquent tenants.

7. Management slow to respond to maintenance requests, unavallable to tenants. Tenants do not know who to contact for problems.

8. Tenants less I ikely to volunteer in bullding or particlpate in activities. More vandal Ism in bulldings. Tenants try to particlpate in management by forming formal organizations.

Source: Sadacca, Loux \& Carlson, 1978 
management with respect to other factors and was speclfically almed at locating high-performance management.

\section{Unlverslty of LLineLs' Resident Satisfaction study}

The University of IIIInols' Housing and Research Development Program also found evidence that management is an important aspect of tenant satisfaction. Several management measures of attitudes, policies, and performance were found to be important predlctors of overall satisfaction in assisted housing (Francescata et al., 1979).

The Housing Research and Development Program conducted research from 1972 to 1977 on resident satisfaction in 10 'd and moderate income assisted-housing complexes. In 1977 , with funding from HUD, the Program began research to look at the relationship between tenant satisfaction and design and management of housing projects. One goal of the study was to Identify environmental aspects that affected satisfaction. The second goal was to identify management strategies. Management and design in assisted housing had not been evaluated from the tenant's viewpolnt "with resulting undesirable soclal and operational consequences" (Francescata etal., 1978).

Thirty-seven projects were used in the study with one deslgned for elderly occupany only. The complexes were all assisted housing from various funding programs. Ten were PHAs, 11 were bullt through state housing development 
agencies, 2 through a munlcipal housing development corporation and the remalning 14 by private, I imited-profit, or nonprofit developers. The sltes were located in 10 states, mostly in the East, Southeast, and Midwest.

Sixteen of the sites were in the central city of major metropolitan areas. Another 16 were in metropolitan areas outslde the central downtown area and were called urban. Two were in the suburbs, and three were in rural areas.

An Occupant Satisfaction and Perception Survey (OSAPS) was developed from interviews with tenants, management staff, and researchers from the Urban Institute in Washington, D.C.

One-third of the adult population from each of the 37 complexes were chosen, with a return rate of $32 \%$ from mailed questionnalres. The OSAPS was then administered through an interview with those tenants who had not responded to the or iginal malling and resulted in over 1,900 responses.

The basic findings of the Housing and Research Development study were:

1. Most residents were satisfled with HUDassisted housing.

2. When properly deslgned and managed, HUDasslsted housing was as satisfactory or more satisfactory than housing in the open market.

3. There were no signiflcant differences in levels of satisfaction that were attrlbutable to differences in assistance programs.

4. Many interrelated aspects influenced residents' satisfaction with a high proportion of the total varlance representing satisfaction with other tenants, pleasant appearance, and economic value. 
5. As a whole, the sample residents were a nonhomogeneous population. Differences in sociodemographic characterlstics were perceived more accurately by tenants than by management.

6. The more other resldents in a development were percelved to be slmilar to oneself, the higher the level of satisfaction with other residents.

7. The perception that other residents were friendly and well-behaved was an important component of overall satisfaction.

8. Not feeling stigmatized for living in assisted housing was strongly assoclated with overall satisfaction.

9. The appearance of the physlcal environment was an important component of resident satisfaction.

10. Perceptions of spaclousness and privacy were moderately strong predictors of overall satisfaction.

11. Location was found to be associated with satisfaction, but was not a controlling factor.

12. Density was not a predictor of resident satisfaction.

13. Smaller projects tended to be only slightly more successful.

14. The type of slte layout was not related to resident satisfaction.

15. There were no slgnificant differences in overall satisfaction between living in high-rise vs. low-rise developments.

16. The type and quality of the facllities and amenities provided were moderately strong predictors of satisfaction.

17. Management aspects were strong predictors of resident satisfaction.

18. A number of management policles and rules were percelved as unsatisfactory by the residents.

19. Management's performance in providing adequate maintenance and in responding quickly and effectlvely to tenants' complaints was generally not satisfactory.

20. Protection from crime and vandalism was Inadequate.

21. Live-in resident managers were not perceived as performing better than managers living off slte.

22. HUD management guldes recelved mixed evaluation.

23. Rent policles were a frequent cause of complaints.

(Francescato et al., 1979) 
The University of IIIInols' Housing Research and Development Program research recommendations are simllar to the Urban Institute's. A firm, responsive management style becomes an integral factor contributing to a project's success (Francescato et al., 1979).

\section{Elderly Asslsted Housing: Recommendations}

Yersus Regulations

Management of assisted projects for elderly and handicapped tenants is consldered to be less difflcult than management of multi-famlly projects (Francescato et al.. 1979 ; Sadacca et al., 1976; Sadacca, Loux \& Carlson, 1978; Welcher, 1980). Only recently, however, researchers have noted that the population of very frall elderly is increasing in those projects, and that adequate management resources needed to manage are unavallable (Bernsteln, 1982a, 1982b). There can be chronic complaining, alcohollsm, confusion over rent payments and recertifications, damaged units due to falling faculties, and sulcldes (Lawton, 1975). In areas with a large selection of elderly designed projects, there is tenant turnover and vacancies (SImmons, 1984; Wolfe, 1984). In January of 1985, HUD occupancy speclalists began a national study to pinpoint exactly where and why those vacancles exist (Schenk, 1984).

The special needs of projects with older tenants have concerned researchers for the past two decades (Andreae, 
1978; Carp, 1966; Green, Fedewa, Johnston, Jackson \& Deardorff, 1974; Lawton, 1975; Regnler \& Byerts, 1983), and federal pollcies for construction and location of projects for elderly and handicapped have been influenced by research recommendations. Basics such as emergency call systems in units, entry call systems for securlty, handlcapped access, design of units for handicapped, community access and location of sites near amenities such as shopping, have become standard requirements (National Housing Law Project, 1982). Research on management practices of elderly projects has not had a similar impact.

\section{Research Recommendations}

M. Powell Lawton, a foremost authorlty on housing older adults, discusses basic management requirements in his book entitled, Plannlng and Managlng Houslng for Elderly, published in 1975. What he sald then has been echoed by others and is pertinent in the 1980's.

Managers of elderly projects should have some gerontological training to enable them to recognize signs of depression, drug problems, alcoholism, paranola, sulcidal tendencies, and falling physlcal abllitles (Butler \& Oldman, 1983; Heumann \& Boldy, 1982; Huttman, 1977; Koldony, Baron \& Struyk, 1983; Lawton, 1975; SIavik, 1981; U.S. Department of 
Housing \& Urban Development, 1979; Woodward \& Wakefleld, 1982).

Managers should be social activity coordinators (Brauer, 1976; Butler et al., 1983; Heumann et al., 1982; Huttman, 1977; Kolodny et al., 1983; Lawton, 1975; Parker, 1984; Sanzotta, 1979; U.S. Department of Housing \& Urban Development, 1979 ).

Managers need to possess:

1. communication and Intervlewing skllls (Heumann, et al., 1982; IREM. 1970; Lawton, 1975; Rose, 1978; Slavik, 1981 ; U.S. Department of Houslng \& Urban Development, 1979); 2. service referral skllls (Brauer, 1976; Fuchs, 1977; Heumann, et al., 1982; Hughes, 1976; Huttman, 1977; Lawton, 1975; Parker, 1984; U.S. Department of Housing \& Urban Development, 1979);

3. an ability to maintain community relationships (Huttman, 1977; Kolodny et al., 1983; Lawton, 1975; U.S. Department of Housing \& Urban Development, 1979); and

4. a personality that works well with older people (Heumann et al., 1982; IREM, 1970; Kolodny et al., 1983; Parker, 1984).

Research with management of elderly assisted housing in Great Brltain has reached simllar conclusions (National Corporation For Care of Old People, 1973). The on-site managers, "wardens," are discussed in simliar terms by Edgar Rose (1978) in Heusing Eor The Aged. He reported: 
1. The need for further study of wardens' roles and attitudes;

2. the need for improved warden-tenant contact;

3. the need to help tenants who become disabled to obtain services; and

4. the need to understand the wardens' role in coordination of the total project.

Alan Butler and Dr. Christine Oldman in an article in Houslng lament the fact that wardens are undertralned, underpaid, and not selected carefully for the responsibilIties they must assume. They are expected to be:

Patient, resourceful, understanding with a sense of humour and sympathy and understanding of old people.. and be able to serve tenants without favoritism, with discrimination, but at all times respecting their independence and individuality (Butler \& Oldman, 1983).

The HUD policles for managers of elderly housing are simllar to the cited research recommendations. The following guidelines were addressed in a HUD-published (1983) Instructors' handbook for training managers of assisted elderly projects:

1. Communication

Speak clearly to older residents. Speak loudly only when talking to resldents who are hard of hearling.

Listen carefully to older residents and clarlfy statements that you do not understand.

Be patient with older residents who respond slower. 
2. At+Itudes

A good manager should exam ine his or her ow motives and attitudes toward aging to overcome misconceptions.

3. Services

A good manager should be sure that older adults are referred to the services they need.

A good manager should insure that new residents obtain the emotional support necessary for adjustment to thelr living situation. One way of doing this is involving residents in social and activity orlented groups within the development.

A good manager should provlde services or activities necessary to support the emotional stablilty of residents. This can be done by organizing residents into soclal or activity orlented groups to promote interaction among residents as well as recreation and constructive activity.

A good manager should know when to seek professional advice for severe emotional problems.

4. Soclal Act|vities

Managers should provide opportunitles for residents to satisfy their needs for status and feelings of self worth. These needs may be fllled through group interaction at the housing unit or at an outside senlor center.

Managers should allow elderly resldents as much independence as posslble. They should be encouraged to $c$ lean or shop for themselves. Management should provide the necessary support for such activity such as lightwelght cleaning equipment and transportation.

Managers should inform older residents of educational opportunities and should motivate them to utllize such opportunities. 
Managers should be particularly sensitive to the needs of women who have been depenoent on husbands for making important decisions all thelr lives. Managers should encourage them to become more independent.

Managers should be careful to recognize cultural and raclal differences when planning programs and interacting with residents.

5. Economics

Managers should insure that residents utilize services avallable to them in the community.

Managers should conslder the low incomes of the elderly when planning outings and trips.

Managers should inform older resldents of the variety of income sources avallable to them and encourage older residents to utilize such resources.

Managers should assist older residents with budgeting when necessary (HUD Management Guldel (nes).

All these recommendations are for people:

1. In an underpaid profession (Heumann et al., 1982;

Lawton, 1975);

2. On whose shoulders the success of a project rests (Heumann et al., 1982; Kolodny et al., 1983; Ralston \& Ralston, 1983); and

3. the bulk of whose duties is record keepling and reportwriting (Fitzgerald, 1979; Huttman, 1977; Lawton, 1975). 
Management Regulations

Regulations are necessary to insure that managers know:

1. How to legally select tenants;

2. How to verlfy that teriants quality for assistance;

3. How to obtain the proper certification;

4. Discrimination regulations;

5. How to complete tenant el igibility forms;

6. How and when to recertify;

7. How to keep waiting lists;

8. How to reject unsuitable applicants;

9. How to complete HUD occupancy forms;

10. Penalties for late recertifications; and

11. How to flll out clalm worksheets.

(Oregon State, 1984)

Somewhere between the ideal world of research-based policies for management and the mandatory world of federal regulations, there is the world of managing assisted housing for elderly mandated by cost control.

\title{
Lecus ef Centrel and Management \\ ef ELderLł Hous Ing
}

\begin{abstract}
A second research toplc consldered with this present study was locus of control. It was hypothes zzed that lowincome seniors might percelve more internal control over
\end{abstract}


their environment if management was firm, fair, and responsive, l.e., where an on-site manager with definite office hours could respond to tenants' requests in as timely a manner as possible, enforce necessary regulations firmly and fairly, and be a source of service referral.

The concept of locus of control arlses out of the social learning theorles of Jullan Rotter (Rotter, 1954, 1966, 1971; Rotter \& Liverant, 1962) where reinforcement of behavior developed from one's perceptions.

In Dehavioral studies, the reinforcement itself is the key to behavior (Skinner, 1974). The relnforcer can be as tangible as food or as intangible as soclal approval.

In locus of control theorles, perception of control is the relnforcer, and if experlences are not seen as the results of one's own actions, they do not alter the way a person sees things and functions (Rotter, 1954, 1966, 1971). Researchers have used both laboratory animals and human subjects to experimentally manipulate percelved control. Some of the foremost animal studies were done with dogs (Seligman, 1968, 1975a; Seligman \& Maler, 1967; Seligman, Maler \& Solomon, 1969), who were given shock treatment in escapable or Inescapable situations. The dogs who had been in escapable situations in the $|n|+\mid a l$ phases attempted to get out in inescapable trials. Dogs in the Inescapable situations in the initial phases were unable to percelve they could escape in subsequent phases. They would 
cower in the shock box and could only be taught to use the escape route by repeatedly beling dragged out. InItially they learned they were unable to control the situation, and when escape was avallable they behaved helplessly.

Curt Rlchter (1959) found that wlid rats, when constralned by beling held tightly before beling placed in a bucket of water would swim to the bottom and die. Autopsies demonstrated that the rats did not drown. Unconstrained wlld rats could sw im up to 80 hours before drowning. It was concluded that restrlcting the rats' kicking and biting behavior resulted in perceived helplessness. These anlmal studles and others on locus of control lead to the phrase "learned helplessness" (Lefcourt, 1976; Sellgman, 1975a, 1975b).

\section{Lecus of Centrol Studles}

with Human subjects

Using elther percelved controllable or uncontrollable aversive stimull on human subjects affects performance on simple tasks such as number comparisons or letter finding (Glass, Singer \& Frledman, 1969; Glass, Reim \& Singer, 1971). The subjects, distracted by stimuli they could not eliminate or anticlpate, did poorly. Subjects performed better if they could anticlpate the stimuli (predictability) or think they could stop it (perceived control). 
In other studles (Phares, 1971), subjects were given chlps to wager on thelr success in matchlng shades of gray or lines of varylng lengths, and then told that success was due to either "skill" or "luck." After each trlal the subjects were given the same feedback of successes or fallures, and asked to wager on the expectancy of belng correct on the next trlal. Reinforcement of "skill" conditlons had a great effect on the way in which subjects set their expectations. "Luck" subjects were more likely to stand pat after success or wager more after fallure. Changes in number of chlps wagered were greater when subjects were given "skill" Instructions. These studies indlcate that knowledge of the subject's perception of control in a laboratory situation could predict the judgments they would make in response to success and fallure.

These studies and many more (Lefcourt, 1976; Rotter, 1966 ; Seligman, 1975a, 1975b) can be generallzed to situations where percelved loss of control of Individuals in socio-economic status, institutions, learning situations, or during traumatic experiences affect behavior.

Early in the developing of locus of control, Jullan Rotter (1966) developed an Internal-External Control Scale (1-E Scale) as a measure of individual differences in bellef of internal versus external control. High internals on Rotter's scale perceive the outcome of 1 ife events as contingent upon thelr own behavior. High externals perceive 
the same events as the results of luck, chance, or others (Rotter, 1966).

Results of use of the I-E Scale over the years indicate that internal percelved control bellefs are assoclated with better psychological adjustment, and external percelved control bellefs are related to indexes of maladjustment (Reld, Haas \& Hawkings, 1977; Wolk, 1976).

\section{Learned_HelpLessness}

The theoretical concept of learned helplessness is the outgrowth locus of control studies where subjects, who percelve over time that they have little or no control over environmental outcome, react helplessly.

Thls is clearly stated in Seligman's book, Learned Helplessness (1975b):

". - a person or anlmal is helpless with respect to some outcome when the outcome occurs independently of all his voluntary responses."

There are individuals who become helpless only after repeatedly experiencing overwhelming traumatlc losses, and others who display helpless behaviors all of their Ilves. Even Seligman's dog trials came up with a small percentage of dogs who were restralned in the initial shock situations but escaped when escape was offered. A simllar small per- 
centage of dogs were helpless at the outset, even in initial escape situations.

Individuals are different. There are differences in perceptions of experiences and differences in reactions to loss of control in traumatic situations. Aglng brings with it a series of losses, albelt at different levels and rates, but losses nonetheless.

As individuals age, a series of unavoldable life events occur. Not all events occur for all individuals, but advancing age wlll, In some way, affect everyone (Lawton, 1975, 1980; National Center for Soclal Policy, 1979).

Children leave home. Thls may be a joyful event for some, but for others it means the end of an important life role.

Retirement produces role changes. Long-awaited, happliy anticlpated retirement has different effects from forced retirement. A person may be forced to stop working because of employment practices, physlcal deterioration, or the economy. Along with retirement, income changes create loss. The upper-income retiree who is prepared for retirement will not experience the trauma of reduced income that most older adults face; for some the loss can be staggering. Lowered income, falling health, or both can facilltate the loss of a home, or make that home extremely difflcult to manage. A forced move to a smaller living unit can bring losses in personal possesslons, in nelghbors, and even con- 
tact with frlends. A move to a federally-assisted unit brings the living within restricting regulations: no pets, personal income must be disclosed, and a medical report must be provided to assess physlcal capabilities (Fitzgerald, 1977).

Death brings loss of a spouse, friends, relatlves, and possibly all three. Loss of physlcal or mental capabilities can bring institutionalization and, depending on the institution, a total loss of control over the lmmediate environment. There is evidence to indicate that when individuals begin to belleve that their actions have no Influence on the outcome of events, a state of learned helplessness, simllar to depression, occurs (Hooker, 1976).

In a study of environmental loss in an institution (Langer \& Rodin, 1976), researchers divided nursing home residents into two groups. One group was told they had cholces as to when they wanted to have movies and what movies they would see. They were asked if they wished to choose a plant and, if so, were told they would have to care for it. They were told this nursing home was their home and if they wanted changes in their rooms, they could make them or have them made.

The second group was told this was their home, and that the aldes would take care of them. They were handed a 
plant and told the staff would water it. Movies were shown on Friday nights and everyone was expected to attend.

The "cholce" group was compared to the "controlled" group by staff observing their interactions. The "cholce" group soclalized more, contacted more nelghbors, and expressed more residential satisfaction.

Similarly demonstrating how small decisions affect elderly institutionallzed residents, Richard Schulz (1976) had four groups visited by volunteers. The assumption was that having a visitor is a pleasant event for aged residents in nursing homes. Subjects in the first group chose when their visitors came and how long the visit lasted. Those in the second group were told when the visit would be and how long it would last. The third group was visited randomly, and the fourth group was visited only to gather data. These were seemingly small decisions allowing one group predictabllity and control.

The results indicate the first group rated significantly healthler than the three control groups and had significantly less increase in medication. The randomly visited group did not have signiflcantly higher scores than the no-treatment groups in Schulz's research. It was thought that the visits would be a pleasant experience for all. The study concludes that the predletability of visits may have been of more benefit. 
Several studies have found that life satisfaction scales of elderly subjects correlate with Rotter's I-E scales. Individuals with higher life satisfaction scores are higher internals on the l-E scales. Brandt (1979), Chang (1978), and Fawcett, Stoner and Zepelin (1980) correlated the scales on Institutionalized elderly. Kabat (1980) correlated I Ife satisfaction scales and the $1-E$ scales on what she termed "young old" and "old old" elderly. Zelgler and Reld (1979), in two separate studles, found a direct relationship between self-concept and locus of control in both institutionalized and noninstitutionalized elderly.

In one study, 77 residents of a nursing home were given an internal-external locus of control scale along with flue indices of life satisfaction. The locus of control scale correlated significantly with a life satisfaction index, a self-concept scale, a positive/negative mood measure, and a subjective senescence scale. Whlle there was no correlation on a tranquility scale, the researchers felt the hypothesis of correlation of perception of control to I Ife satisfaction was demonstrated.

In the other study (zeigler et al., 1979), 88 residents of six nursing homes and 65 elderly living independently were administered the locus of control scale and self-concept measures. Overall results were that internal control over desired outcomes was assoclated with more con- 
tentment and a higher self-rating on a happiness scale. There were little differences between institutionalized and noninstitutionalized groups as a whole, but higher correlations for institutionalized males as in the first study.

In another study it was discovered that training elderly in assertiveness skills raised Internal scores on the 1-E scales (Reakes, 1980), and It was al so found that internal and external locus of control scores can be Influenced by positive orlentation to the environment (Hunter, Linn, Harris \& Pratt, 1980).

Stephen Wolk (1976) found in a study with elderly subjects some relationship between living situation and Internal control scores. His thesis was that a given living situation might influence some adjustment of a person's locus of control.

He chose older adults with similar socio-economic standing from two retirement situations and administered a locus of control scale along with other measures. Subjects in the "low constraining" setting demonstrated higher internal control than the subjects from the "hlgh constraining" setting.

In a paper by Nehrke and Reimanes (1978) when a group of Institutionalized male subjects were compared to a group of male subjects living in the community using Rotter's $1-E$ scale, the institutionalized males had significantly higher 
internal scores. This led the authors to speculate that the Institution provided a secure, sheltered setting with more personal control allowing a sense of mastery and even satisfaction with the institutional situation.

While assisted-housing projects are not institutions, older residents are likely to have faced losses of income and privacy in order to qualify, and wlll face additional losses as they age. On the basis of past research, where seemingly small cholces offered to institutionalized elderly affected their perceptions of inner control, it seemed reasonable to examine the idea that management style would become a factor affecting older tenant's perceptions of internal control.

\section{Summary}

The problems of assisted housing are many, with a past history of operating deficlts and a more recent hlstory of budget cuts (Pollkoff, 1978; Sadacca et al., 1976; Stegman, 1980; Struyk, 1980). Also, additional evidence suggests that assisted-housing projects designed for elderly and handlcapped resldents are developing vacancy problems in some areas of this country (Schenk, 1984, Simmons, 1984; Wolfe, 1984).

Problems contrlbuting to projects' budgetary troubles can be attrlbuted to many factors; however, the body of research indicates that management style is a major consid- 
eration, and that management's attltude toward residents Influences how well a project functions (Conrad, 1970; Fitzgerald, 1977; French, 1977; Onibokun, 1974; Porco, 1980; Welcher, 1980; Wollock, 1977).

A series of studies at the urban Institute of Washington, D.C., reported that an on-site, firm, falr, responsive management style impacts positively both resident satisfaction and bullding cost performance (Isler, 1974; Sadacca et al., 1976; Struyk, 1980).

While the same style holds true for asslsted projects designed for elderly and handicapped tenants, the special needs of aging adults requires the added factors of gerontologlcal trainlng and service referral skills for management (Lawton, 1975). But the declding factor in the design of management has been economic, and few managers have the recommended skllls (Heumann et al., 1982; Huttmann, 1977; Lawton, 1975).

With the management of assisted housing for seniors as the focus of this dissertation, an examination of locus of control and learned helplessness theorles in relationship to management style was carrled out. There is some evidence to Indicate that offering aging residents in institutional settings some small control over facets of their environment contributes to perceptions of internal control (Langer \& Rodin, 1976; Schulz, 1976). 
CHAPTER IV

THE STUDY

Research findings from the Urban Institute management studles (Sadacca et al., 1976) and the University of III inols' Housling Research and Development Program (Francescato et al., 1979; Weldman et al., 1980), were based on data gathered from assisted-housing projects already in operation.

The objective of this dissertation was to model those management styles in a newly opened assisted-housing project for the elderly and handicapped. The studies clted were largely focused on multi-family projects. Of the 120 PHA projects and 60 privately owned projects in the Urban Institute research, $47 \%$ of the tenants were elderly. In the Housing Research and Development Program study, of the 37 projects, 36 were multi-famlly and one was for elderly. While projects for seniors may not have the management problems of multi-family projects (Francescato et al., 1979; Sadacca, Loux \& Carlson, 1978), there are problems: tenants become increasingly frail, become confused about money responsibilities, recertification, or apartment inspection requirements. In addition there are drinking problems, mental problems, and chronic complaining. 
In the Urban Institute's management guidelines for high performance projects, authorlty was based on-site and management was a source of servlce Information (Isler et al., 1974; Loux, \& Sadacca, 1975, 1977; Sadacca et al., 1976; Sadacca, Loux, \& Carlson, 1978).

In the literature on management of housing for elderly tenants, researchers recommend that managers have gerontology and service-referral training (Heumann, et al., 1982; Lawton, 1975; U.S. Department of Housing and Urban Development, 1979).

This study sought to institute those guidel ines in a newly opened asslsted-housing project for elderly and handicapped: Bullding $A$, in the city center of Portland, Oregon. For comparison three assisted projects for elderly and handicapped tenants with management styles that differed from Bullding A were selected (see Table II for bullding descriptions).

The owners and developers of Bullding $A$ agreed to this research plan early in the rehabllitation of the bullding. The original plans included a 2-bedroom, live-in manager's apartment. The owner changed some interlor construction plans to allow for a 1 -bedroom assistant manager's apartment with a separate space for an on-site manager's offlce. Housing research indicates that "on-site," not "I ive-in," Is cruclal to resldent satisfaction (Francescato et al., 1979). 
TABLE $\|$

BUILDING DESCRIPTIONS

\begin{tabular}{|c|c|c|c|}
\hline Bullding $A$ & Bulldlng $B$ & Bullding C & Bullding $D$ \\
\hline $\begin{array}{l}\text { Privately Dev. Sec. } 8 . \\
\text { Rehabliltation }\end{array}$ & $\begin{array}{l}\text { Privately Dev. Sec. } 8 \\
\text { Rehabilitation }\end{array}$ & $\begin{array}{l}\text { PHA, Conventional } \\
\text { New Construction }\end{array}$ & $\begin{array}{l}\text { PHA, Section } 8 . \\
\text { New Construction }\end{array}$ \\
\hline $\begin{array}{l}84 \text { Units, } 641 \text {-bdrm. } \\
20 \text { studios, Indoor } \\
\text { atrlum w/skyl ight. } \\
16 \text { unlts have no } \\
\text { windows to outside. } \\
\text { Opened } 11 / 4 / 85\end{array}$ & $\begin{array}{l}56 \text { Units, } 35 \text { 1-bdrm. } \\
21 \text { studios. }\end{array}$ & Opened $9 / 8 / 81$ & Opened $8 / 5 / 80$ \\
\hline $\begin{array}{l}\text { City center location. } \\
\text { One block from super- } \\
\text { market. Half-block } \\
\text { to bus. Four blocks } \\
\text { to city center } \\
\text { shoppling, theatres, } \\
\text { etc. One block from } \\
\text { library. Two blocks } \\
\text { to medlcal bulldings, } \\
\text { pharmacy. }\end{array}$ & $\begin{array}{l}\text { City center location. } \\
\text { Two blocks from super- } \\
\text { market. Hal f-block to } \\
\text { bus. Three blocks to } \\
\text { city center shopplng, } \\
\text { theatres, restaurants. } \\
\text { Three blocks from } \\
\text { medical buildings, } \\
\text { pharmacy. }\end{array}$ & $\begin{array}{l}\text { N.W. area adjacent to } \\
\text { city center. Two } \\
\text { blocks from super- } \\
\text { market. Small shopping } \\
\text { area, restaurants } \\
\text { around corner. Varlety } \\
\text { of secondhand stores, } \\
\text { novelty stores. Hal f- } \\
\text { block to bus. }\end{array}$ & $\begin{array}{l}\text { N.E. residentlal area. } \\
\text { Two and-a-hal f blocks } \\
\text { to two supermarkets. } \\
\text { Three blocks to large } \\
\text { shopplng center, } \\
\text { novelty stores, } \\
\text { restaurants, skating } \\
\text { rink, doctor's office. } \\
\text { Two blocks to bus } \\
\text { stop. }\end{array}$ \\
\hline $\begin{array}{l}\text { Entry system. Tenants } \\
\text { speak to visitors, see } \\
\text { them, buzz them in. }\end{array}$ & $\begin{array}{l}\text { Entry system. Tenants } \\
\text { can speak to visitors, } \\
\text { buzz them in. }\end{array}$ & $\begin{array}{l}\text { Entry system. Tenants } \\
\text { can speak to visitors, } \\
\text { buzz them in. }\end{array}$ & $\begin{array}{l}\text { Entry system. Tenants } \\
\text { can speak to visitors, } \\
\text { buzz them in. }\end{array}$ \\
\hline
\end{tabular}


Building A opened in November of 1981 with a fulltime, on-site manager and a live-in assistant responsible for bullding maintenance.

The manager's responslbilitles were:

1. Tenant selection, certification and recertification.

2. Setting up social activities.

3. The monthly newsletter.

4. Seeing that malntenance and contract repairs were made.

5. Contracting out necessary repairs and maintenance.

6. Preparation of monthly government reports and correspondence.

7. Preparation of monthly income journal.

8. Collecting rents.

9. Evictions.

10. Handing complaints.

11. Service referral.

12. Seeling that regulations were adhered to.

13. Hiring and supervising the assistant managers.

Care was taken during the Interview process to clarlfy resident expectation of both tenants' and management's responsibllities (Porco, 1980). The project was introduced as the new tenant's "home" (onlbokun, 1974). Definite onsite offlce hours were set up and tenants knew whom to contact for requests or complaints. A tenant handbook was 
given to new residents. Management was a source of service referral (Lawton, 1975). New residents confused as to how to get certiflcation verlfication were given assistance. Recertifications were handled in the same manner, with help given to those tenants who found it difficult to obtaln the information necessary for federal requirements.

The "I ive-in" assistant manager was responslble for general malntenance, minor repairs, and emergency calls after hours. There was a tenant-alde with an emergency call device in his unit to cover the project for emergencies when the assistant manager was out during an evening or over the weekend.

In Kezs to Successful_Management (I sler et al., 1974), management authority for higher performing projects is based "on-site." Rules are adhered to, and problem tenants evicted promptly. The manager knows tenants by name, and tenants know who to contact for assistance. Malntenance calls are responded to reasonably promptly. Management is a source of service information.

\section{Lndependent Varlable: Management_style}

In Building $A$, the management style reflected the research recommendations where:

1. Authorlty for the project was based on-site. Maintenance was based on-site. 
2. Management was a source of service information.

3. Management had a background of gerontological and service referral tralning and experience.

Bullding B is a privately developed Section 8 project located in the city center of Portland, one block from Building A. Simllarlty of location was the reason for selecting Bullding B. The on-site managers are a couple whose responslbilities include general maintenance. They are on-site approximately half-days, five days a week. Along with the maintenance, they select, certify and recertify tenants. The assistant manager is a Iive-in resident responsible for answerlng emergency calls when the managers are away from the bullding (Garver, 1984, 1985).

Bullding $C$ is a conventionally funded PHA project selected because of the proximity of date of opening to Bullding A--September of 1981. Bullding C Is located in Northwest Portland near the city center.

Bullding D, owned and operated by the same PHA, is a Section 8 funded project located in a residential area of Portland near a large shopping center. Management of $C$ and D is the same. Authorlty for both projects is centralized at the PHA central offlce. Tenant selection is made at a central office. Malntenance requests are made to a malntenance department. Managers are service coordinators who are on-site only a few hours a week. Service coordinators do the certification and recertification of tenants and have 
a caseload of approximately 380 tenants, encompassing three or more bulldings and section 8 certificate holders. There is a resldent-alde in each bullding responsible for answering emergency calls after PHA offlces hours (Greenough, 1984; Jackson, 1984, 1985; Otness, 1983, 1984).

Differences in management style between the four bulldings were determined by job descriptions, interviews with managers, and questionnalres given to managers (Garver, 1983, 1984; Jackson, 1984, 1985; Otness, 1983, 1984).

The administrator of Bullding $A$, on five separate occasions, maintained a dally iog in an attempt to identify the nature and frequency of behavior of management to tenants. The managers of $B, C$, and $D$ al so repeatedly were requested to keep logs. However, the constraints of their jobs did not permit them the opportunity to maintain dally logs. See Table $\| 11$ for management differences.

Major differences In management style Include:

1. Project-based responsibility for tenant selection.

2. Project-based authority for bullding responsibllities.

3. Project-based maintenance responsibilities.

4. Management involvement in social activities.

5. Management as a source of service-referral.

6. Management tralning. 
TABLE $\|1\|$

INDEPENDENT VARIABLE: MANAGEMENT STYLES




7. Management contacts with tenants by administrative attendance at weekly coffee hours, monthly potlucks, holiday parties, and distribution of a monthly newsletter.

\section{Hypetheses}

Thls study sought to Identify differences in bullding performance between Bullding $A$ and $B u i l d i n g s ~ B, C$, and $D$. It was hypothesized that:

1. Tenants from Building A would have higher internal scores than tenants from Bulldings $B, C$, and $D$ on the Now ickl-Strlckland Internal-External Control Scale (ANS-IE).

2. Tenants' satisfaction with bullding management would be higher for Building $A$ when compared to Bulldings $B$, $C$, and $D$ on the Occupant Satisfaction and Perception Survey (OSAPS) from the University of IIIInols' Housing Research and Development Program.

3. Tenants from Bullding $A$ would participate in volunteer activities at a higher rate than tenants from $B$, $C$, and $D$ as measured on the OSAPS.

4. Bullding $A$ would have a lower tenant turnover rate than Bulldings $B, C$ and $D$. Data would be taken from project records.

5. Bullding A would be more cost efflclent per unlt than Bulldings $B, C$, and $D$ using data gathered from operating costs. 
Eirst_HzRethesis:_Lnternal_contrel

and Hous Lng Management

With this present study it was thought that by offering older residents in assisted housing seemingly small factors of predictabllity by informing them of management responsibilities, responding to malntenance requests efficientiy, seelng that regulations were falrly well adhered to, and having management as a source of service referral, a slightly higher measure of internal control perception would be significant for the residents of Building $A$.

\section{Second Hypothesls: Resldent Satisfaction}

The Urban Institute management studies find some relationship of higher resident satisfaction in those assisted housing projects where there are on-site, firm, fair, and responsive management practices (|sler et al., 1974; Loux et al., 1975; Sadacca et al., 1976).

Similarly, the Unlversity of lllinois' Housing Research and Development Program finds that:

Management aspects are strong predictors of resident satisfaction, where tenants perceive management as respectful, frlendly, cooperative, policles and rules were appropriate and fairly and equally enforced, repalrs were made promptly and malntenance was adequate (Francescata et al., 1979; Anderson et al., 1979). 
Ihird_HzRothesis: Tenant VeLunteerism

The Urban Institute management studies found a relationship between tenant activity to higher performing projects. Where "tenants volunteer in and around a bullding, are active in bullding activities... [they are] less likely to want to particlpate in management" (Isler et a (., 1974).

It seemed a natural outgrowth of this present study to attempt to measure tenant activity. Tenant volunteerism in an assisted-housing project for older adults could prove to be valuable for frall resldents if the other tenants helped them out. With a greater frall tenant population (Bernsteln, 1982a, 1982b), volunteerlsm by the more able bodled should be a positive factor.

\section{Eourth and Fifth Hypotheses: Tenant}

\section{Iurnever and Cest Per Unit}

Tenant turnover rates and cost per unit were two factors used in the Urban Institute research to measure bullding performance (lsler et al., 1974; Loux et al., 1977, 1980; Sadacca \& Loux, 1978; Sadacca, Loux \& Carlson, 1978). The most vital factor in building performance is costs. The body of research demonstrates hlgher resident satisfaction In higher performing bulldings with firm, falr, responsive management, but resident satisfaction is not the varlable to influence instituting that management style. 
Tr lypotheses of cost per unit and tenant turnover sought to demonstrate that management with authority at the project level costs less. Cost is a factor which owners and operators are sensitive to in hiring and training professlonal managers. If the professional manager's duties correspond with the needs of the projects, the resulting benefits should produce a "well-maintalned and financlally sound" project.

\section{Dependent Varlables}

The dependent variables are:

1. Tenant Internal control scores from the Adult Now icki-strickland Internal-External Control Scale (ANS-IE) (Nowlckl \& Duke, 1973). The ANS-IE was chosen for this study because it Is consldered more readable than Rotter's I-E Scale (Nowickl et al., 1973).

2. Tenant satisfaction with building management as measured by questions taken from the occupant Satisfaction \& Perception Survey (OSAPS) (Anderson \& Weldmann, 1979). The OSAPS was used with this study because of demonstrated rellability measures made of the scales (Anderson \& Weldmann, 1979). No rellabllity measures were made on questionnaires used during the Urban Institute studies (Sadacca, 1981).

3. Tenant participation in building activities, also measured by questions from OSAPS. 
4. Tenant turnover rates taken from vacancy records of the three management organizations responsible for the four buildings.

5. Operating costs per unit for one year, al so from project records. 


\section{CHAPTER $V$}

\section{ME THODS}

Bullding $A$ opened in November of 1981 with a fulltime, on-site manager and a live-in assistant manager responsible for building maintenance.

The research deslgner for thls study served as the project manager of Bullding $A$. Consclous effort was made to adhere to management characteristics cited earlier.

1. Tenants were introduced to the project as their home.

2. Tenants were treated courteously.

3. Every effort was made to clarify the certification process and rule expectations.

4. Tenants were kept informed of management duties and responsibilities.

5. Maintenance requests were responded to as soon as feasible with an explanation given for any delays.

6. Communication in the form of newsletters or announcements was designed to explain announcements and regulations without being authorltarlan.

7. Management learned the names of all tenants and greeted them accordingly.

8. Management provided service referral as needed. 


\section{Research_BuLIdings}

Three assisted-housing projects for elderly and handlcapped resldents were selected to compare bullding performance (see Table II In Chapter IV).

Major differences in management style included the more frequent contact of Building A's management with tenants, the project-based responsibllity for tenant selection and malntenance, and management involvement with social activities and service referral (see Table $|1|$ in Chapter (V).

Thirteen months after the opening of Bullding $A$, a questionnaire was malled to all units in the four bulldings. The questionnaire contained scales taken from the occupant Satisfaction and Perception Survey (Anderson et al., 1979) and the Nowickl-Strickland Internal-External Control Scale for Adults (Nowlckl \& Duke, 1973).

\section{Lnstruments}

lecupant Satisfaction and Perception Survey

The University of III inois' Department of Housing Research and Development Program received funding from HUD durling the late 1970 s to research measures of residential satisfaction with the intent of finding ways to improve housing satisfaction. 
The Occupant Satisfaction and Perception Survey (OSAPS) was developed through research on prevlously used instruments, discussions with residents and management personnel from subsidized projects and discussions with researchers from the Urban Institute's management studles.

Three preliminary versions of OSAPS were developed by the Housing Research Program at the University of IIIInols, and the final version was tested for clarlty with residents in a housing complex not included in the final research study. Comments were sought so questions would be clear to all tenants (Anderson et al., 1979).

Test-retest data was gathered from 27 respondents with the satisfaction index from the first test correlating with the satisfaction index in the retest $w i t h r=.87$.

The OSAPS was then given to another 32 residents three times at one-week intervals. Week two correlated with week one at $L=.849$, week three $w i$ th week one at $L=.835$, and week two with week three at $L=.947$ (Anderson et al., 1979).

Because OSAPS measures so many components not necessary for this study, only those questions relevant to tenant satisfaction in an elderly project were used in this research. Examples of components omltted include: (a) future expectations (w $1 / 1$ have a better job someday), (b) organizational structure (babysltting pool present), (c) recreation (sultable recreation for toddlers), 
(d) refuse concern (not much trash around garbage cans), and (e) parking (satisfled with parking). The very size of OSAPS would have been unwleldly, especially since the resident satisfaction survey was coupled with a locus of control scale.

The components used were:

1. Management (Questions $6,8,9,10,18,19,20,21$, 22 and 23)

2. Safety (Questions 5 and 26 )

3. Volunteerlsm (Questions 12,13,14, 15 and 16)

4. Satisfaction lquestions 1,2, 7, 11,17,24 and 25)

(See Appendix C for a copy of the questionnaire.)

The questions were five-point scale ltems, e.g., "How safe are you from accidents in this building due to such things as abandoned junk, broken glass, poor maintenance? 1. Very Safe; 2. Safe; 3. Nelther Safe Nor Unsafe; 4. Unsafe; 5. Very Unsafe.

Now Lckl-Strlckland Internal-External

Centrel_scale for Adults

The second half of the malled questionnalre was the Now lckl-Strlckland Internal-External Control Scale (ANS-IE) (Nowlckl, 1974). The ANS-IE was developed because of criticlsm of Rotter's orlginal Internal-External Scale on the grounds that Rotter's scale had a high relationship with 
soclal desirabli ity and was difflcult to read (Nowlckl et al., 1973). The ANS-IE was administered along with the Marlow-Crowne Social Desirabllity Scale to two samples of college students $(n=48$ and $n=68)$. The ANS-IE scores were found not to be related to scores from the soclal desirablilty measures $(L=.10$ and $I=.06)$. The ANSI-IE was intended to be written so chlldren could understand it, while at the same time beling appropriate for adults. The authors felt that the difflcult reading level of Rotter's I-E Scale was not appropriate for noncollege populations and was not approprlate for a large segment of the adult population.

Because of the empirical support for Rotter's I-E Scale, the ANS-IE was administered along with the I-E Scale to two college and one community adult samples in an attempt to establish validilty by showing the two scales to be significantly related. The correlations between the two measures were significant with $\Sigma=.68$ and $\Sigma=.48$, supporting the theory that the I-E Scale and ANS-IE assess the same constructs.

The ANS-IE was included along with the questions from OSAPS that were malied to all apartment numbers in Buildings $A, B, C$, and $D($ see $A p p e n d i \times C)$. 


\section{Subjects}

Since 1984, HUD regulations--income IImIts, Income definitions, certifications and recertifications--for all programs, whether PHAs or private developers, are the same. Newly constructed or rehabllitated projects for elderly and handicapped are intended for:

1. Two-person households headed by an elderly person.

2. Single persons who are elderly.

3. Single persons who are handicapped or disabled.

Elderly is deflined as "anyone 62 years of age or older." To quallfy as handlcapped:

A person must have an impalrment which is expected to be of long continued and indefinite duration, substantially impedes his/her abllity to live independently, and is of such a nature that such ability could be improved by more sultable housing conditions" (National Housing Law Project, 1982).

Income I Imits are:

1. Very low - $\$ 6,550$ (single) and $\$ 7,550$ (couple)

2. Lower $-\$ 12,000$ (s/ngle) and $\$ 17,000$ (couple)

The "lower" income range was set by HUD to attract middle income residents to offset federal rent subsidies in Section 8 projects. Regulations require that such projects house at least $30 \%$ of the unlts to very low income residents. In the four research buildings in this study, nearly all of the tenants fall into the very low income range. Samples taken from PHA and Section 8 New Construction/ Rehabllitation programs in 1979 indicate the bulk of tenants 
In those projects have their major source of income from Social Securlty (SS) or Supplemental Securlty Income (SSI), with the greatest percentage of the tenants to be elderly (Soldo \& Brotman, 1981; Warner, 1983; Zals et al., 1982).

Income for subsidized tenants includes all sources of Income: SS, SSI, private pensions, veterans pensions, interest, money recelved from properties, stock and bonds, wel fare, al imony, etc.

Tenants pay $30 \%$ of their total adjusted income. Income is adjusted for out-of-pocket medical expenses over and above $3 \%$ of their income. Costs included in the adjustment Include prescrlptions, glasses, payments to medical doctors over and above Medicare and insurance coverage, payments to dentists, and payments for medlcal insurance.

In those projects where tenants pay their own utilities, rent is adjusted so that the combined rent and utility costs stay within the $30 \%$ of income range for the year.

For example, in Bullding $A$, tenants receive a utillty deduction of $\$ 25.00$ for a one-bedroom unit. A tenant in a one-bedroom with an income of $\$ 400.00$ per month would pay $\$ 95.00$ per month rent and his own utillty blll $130 \%$ of $\$ 400$, less $\$ 25.00)$. In Bullding $B$, where utllitles are included In the rent, the same tenant would pay $\$ 120$ per month rent and no other utllity bllls coregon state Housing Division, $1984)$. 


\section{Procedures}

In December of 1982 , the questionnalre was malled to all 320 units in the four buildings. A cover letter explained the project as a research study of management of assisted housing, and it guaranteed confidentiality isee Appendix B). A dollar blll and a self-addressed, stamped return envelope also were included. A token of payment in a malled questionnalre usually generates a larger response percentage (DIIIman, 1978 ).

The return envelopes were coded with the unit number and bullding code to allow for follow-up mallings. The code for Bullding $A$ was changed to $E$ on the return envelopes. A second malling with a cover letter and stamped, selfaddressed return envelope was malled to non-respondents approximately two months after the initial malling. A third malling was sent to non-respondents approximately two months after the second (see Appendices C and D for cover letters). Between the second and third mallings, a large poster was posted in each bullding giving a time when someone would be in the community room to talk to anyone who wished to discuss the questionnaire. The chairman of the dissertation commlttee for this research met with the tenants at the prescribed times.

Human Subjects

At the outset of this study, there was some concern by 
the Human Subjects Committee at Portland State University about the vulnerability of subjects. The researcher managed Bullding $A$ and knew the managers of Bulldings $B, C$, and $D$.

After the initial mailing to all unit numbers in the four projects, the researcher did not assist with any subsequent malling to avold knowing which tenants had returned questionnalres. All returned questionnalres were sent to the Urban Affairs Department at PSU in care of the Chairman of the dissertation committee for this research.

Questionnalres were given to an outside research consultant to code and program for analysis.

\section{Rate ef Questlennalre Return}

Over the four mallings, 237 questionnaires were returned.

One respondent put the dollar in the return envelope, scratched out the unit number and sent it back. Another tore the bottom off the cover letter and sent back an analysis of the signature. Refusals were accompanied with notes explalning why le.g., poor English, plans of moving, dislike of the questionnalre).

\section{Questlennalre Analysis}

An outslde researcher coded the returned questionnalres and key-punched the computer cards. The coding and 
keypunching were double checked by the consultant, who had designed the program for the sPSS University of Kansas Honeywell conversion on Portland State University's Honeywell 60-10.

Analysis of varlance was used with the management, volunteerism, and locus scales from the questionnalre returns. Analysis of variance is designed for use with both experimental and nonexperiemental data gathered for more than two groups (Kerlinger, 1973; Thorndike, 1982).

Both the Scheffe and the Student-Newman-Keuls procedures were used on the SPSS package to test for slgnificance at the .05 level. The Scheffe and the Student-Newman-Keuls procedures are approprlate for multiple comparisons. The Scheffe procedure makes use of $E$ tables, whlle the studentNewman-keuls uses student range tables. Both tests are consldered stringent for the methods they use (Bruning \& Kintz, 1972).

Analysls of the Locus of Control Scale for this study Included those respondents who answered 32 of the $37-1$ tem scale, and on the 10-item management scale, respondents who answered at least 9 of the Items were Included. On the volunteer ism scale, those respondents who answered all five items on the scale were Included in the analysis. Questions left unanswered on any scale were coded with a 9 (see Relative Frequencles, Appendlx F). 


\section{CHAPTER $\vee 1$}

\section{RESUL TS}

\section{Lecus_of Centrol}

The SPSS analysis of varlance program used with this study on the ANS-IE's two-point response scale indicated no significant differences between groups at the .05 level with Student-Newman-Keuls procedure and the Scheffe procedure (see Table IV).

TABLE IV

ANALYS IS OF VARIANCE OF RESPONDENTS WHO COMPLETED 32 OF THE 37 QUESTIONS ON THE TWO-POINT ANS-IE SCALE

\begin{tabular}{|c|c|c|c|c|c|}
\hline Source & $\begin{array}{l}\text { Degrees } \\
\text { of } \\
\text { Freedom }\end{array}$ & $\begin{array}{l}\text { Sum of } \\
\text { Squares }\end{array}$ & $\begin{array}{c}\text { Mean } \\
\text { Square }\end{array}$ & E Ratio & E Prob. \\
\hline $\begin{array}{l}\text { Between Groups } \\
\text { Wlthin Groups } \\
\text { Total }\end{array}$ & $\begin{array}{r}3 \\
179 \\
182\end{array}$ & $\begin{array}{l}0.0685 \\
3.7117 \\
3.7802\end{array}$ & $\begin{array}{l}0.0228 \\
0.0207\end{array}$ & 1.102 & 0.34 \\
\hline Group & Response & & Mean & $\begin{array}{l}\text { Sta } \\
\text { Dev }\end{array}$ & $\begin{array}{l}\text { dard } \\
\text { ation }\end{array}$ \\
\hline $\begin{array}{l}\text { Building } A \\
\text { Building } \\
\text { Buliding } \\
\text { Building }\end{array}$ & $\begin{array}{l}40 \\
28 \\
54 \\
61\end{array}$ & & $\begin{array}{l}1.747 \\
1.695 \\
1.715 \\
1.698\end{array}$ & & $\begin{array}{l}158 \\
157 \\
137 \\
132\end{array}$ \\
\hline
\end{tabular}

The reliablilty for the entire scale is coefficient alpha $=0.68$. Rellabllity on the internal control questions 
is coefflclent alpha $=0.37$, and for the external control questions, coefflclent alpha $=0.74$.

\section{Satisfactien WLth Management}

Analysis of variance on the ten-question, five-point satisfaction with management scale, using the studentNewman-keuls and the Scheffe procedures indicates that satisfaction with management in Bulldings $A, B$, and $D$ is not significantly different from each other, but that Building C's satisfaction is significantly lower from the three other bulldings at the .05 level (see Table V).

\section{TABLE $V$}

ANALYSIS OF VAR IANCE OF RESPONDENTS WHO COMPLETED AT LEAST NINE OF THE TEN-QUESTION MANAGEMENT SCALE

\begin{tabular}{lccccc}
\hline \multicolumn{1}{c}{ Source } & $\begin{array}{c}\text { Degrees } \\
\text { of } \\
\text { Freedom }\end{array}$ & $\begin{array}{c}\text { Sum of } \\
\text { Squares }\end{array}$ & $\begin{array}{c}\text { Mean } \\
\text { Square }\end{array}$ & E Ratio & E Prob. \\
\hline Between Groups & 3 & 7.9223 & 2.64 & 7.324 & 0.000 \\
Within Groups & 178 & 64.1801 & 0.36 & & \\
Total & 181 & 72.1024 & & Standard \\
\hline & & & & & \\
\hline & & & & & \\
\hline
\end{tabular}


Using the SPSS correlation matrix IIst-wise deletion procedure, the standardlzed ltem coefflcient alpha for rellabllity on the management scale ls .884. The kuderRichardson-21, calculated by hand, Indlcates a coefficient alpha of .824 (Bruning \& Kintz, 1972).

\section{Volunteerism}

Both the Student-Newman-keuls and the Scheffe procedures on the SPSS analysis of varlance programs indicate no signiflcant difference between Bulldings at the 0.05 level (see Table VI).

\section{TABLE V I}

ANALYSIS OF VARIANCE USING RESPONDENTS WHO COMPLETED ALL ITEMS ON THE FIVE-SCALE, FIVE-POINT VOLUNTEERISM SCALE

\begin{tabular}{lccccc}
\multicolumn{1}{c}{ Source } & $\begin{array}{c}\text { Degrees } \\
\text { of } \\
\text { Freedom }\end{array}$ & $\begin{array}{c}\text { Sum of } \\
\text { Squares }\end{array}$ & $\begin{array}{c}\text { Mean } \\
\text { Square }\end{array}$ & E Ratio & E Prob. \\
\hline Between Groups & 3 & 5.1151 & 1.70 & 2.825 & 0.0407 \\
Within Groups & 151 & 91.1213 & 0.60 & & \\
Total & 154 & 96.2364 & & Standard \\
\hline & & & & & \\
\hline & & & & & \\
\hline
\end{tabular}


Ienant_Iurnever_Between_BuLddings

Comparable turnover data from project to project was unavallable. Record keepling varles, and locating preclse Information was not possible. The only comparable data was occupancy data on the 31 st of March, 1984. The last day this researcher was administrator of Bullding $A$, occupancy was as follows:

1. Bullding A - No vacancies Coregon State Occupancy request)

2. Bullding B - No vacancies (Rent collection statement from management $f(r m)$

3. Bullding C - Two vacancies (R. Otness, 1984)

4. Bullding D - Two vacancles (J. Greenough, 1984)

\section{Cost Per Unit}

The operating budgets from the PHA were by year, and the fiscal year ends March 31. The budget used was for March of 1984 .

The privately developed projects had operating budgets avallable by the month, so those months comparable to the PHA's were used to compare costs per unit from April 1 , 1983, to March 31, 1984 .

The problems encountered with three very different operating budgets were a factor in the decislon to use operating malntenance costs only. 
Costs omitted were:

1. Administration expenses, e.g., offlce salarles, offlce supplies, management fees, telephone advertising, I lcense, postage, tenant activities, legal fees, auditing and accounting fees.

2. Operating expense, e.g., electricity, gas, sewer, and water.

3. Debt service.

4. Taxes and insurance.

5. Non-recurring repairs.

These costs were omitted because of agency differences in recording budgets. The PHA in this study allocates some administration costs over all projects under their jurisdiction. The PHA's maintenance department, however, charges its work orders by project, allowing for a reasonable breakdown of malntenance cost per project.

Costs included in the cost per unit were:

1. Malntenance payroll.

2. Repair materlals/supplies.

3. Maintenance equlpment.

4. Contract labor.

5. Elevator contract.

6. Alarm monitor.

7. Pest control.

8. Decorating contract (on-going). 
Total yearly maintenance cost per unit from April 1 , 1983, through March 31, 1984, is represented In Table VII where cost represents the sum of total yearly maintenance cost divided by twelve then divided by the number of units. Calculating cost per unit for the 12-month perlod between Building $A$ and Bullding $B$ using the Mann-Whitney $U$ Test for differences between independent samples (Bruning et al., 1972) indicates a slgnificant difference between the two at the .02 level. The independent samples used in the Mann-Whitney $\mathbb{U}$ Test were operating malntenance costs, divided by the number of units, for each month from April 1 , 1983 to March 31, 1984 .

With the significant differences between per-unit malntenance costs between Bulldings $A$ and $B, i t$ is safe to assume Bullding A's malntenance costs to be significantly different from $C$ and $D$, also.

TABLE VII

TOTAL YEARLY MAINTENANCE COST PER UNIT PER MONTH (APRIL 1, 1983 to MARCH 31, 1984)

\begin{tabular}{cr} 
Bullding & Cost \\
A & $\$ 126.09$ \\
B & 192.63 \\
C & 251.83 \\
D & 244.21 \\
\hline
\end{tabular}




\section{Discusslon of Results}

\section{Elrst Hypothes Is: Internal}

Versus External Control

There is no support in this study for the first hypothesis that respondents from Building $A$ would have significantly higher perceptions of internal control when compared with respondents from Bulldings $B, C$, and D.

The use of the locus of control scale in this study presented problems for the respondents, indicated by the comments written in the margins of the returned questionnaire. Also the SPSS correlation matrix revealed many negative correlations, another indication of problems with the scale.

This hypothesis might have been better served if consldered on its own merit with the locus of control scale adminlstered by interviewers.

\section{Secend Hypothesis: Satisfaction}

With Management

There is also no support for the second hypothesis that respondents from Bullding A would percelve a significantly higher perception of satisfaction with management when compared to respondents from the three other bulldings.

Thls result was unexpected in light of the concentrated effort to provide responsive management in Bullding 
A. The questionnalre results did Indicate some significant differences that required fur ther investigation.

There were signiflcant differences in length of resldency between buildings, explalnable by the different amounts of time each bullding had been opened. There was also a significant difference in the higher education level of respondents from Bullding $A$, when compared to those in the other three buildings.

An analysis of covarlance with length of residency time and educational differences was made. The E tables did not indicate that those differences significantly impacted on questionnaire results (see Appendix $G$ for covariance analysis).

\section{IhIrd Hypothes Ls: Volunteerism}

Analysis of the questionnaires from the four buildings Indicated no support for the hypothesis that volunteerism would be higher in Bullding $A$.

During this research project, some confusion emerged over the definition of volunteerlsm as used in the questionnalre. The hypothesls on volunteerism was included in this study because of earlier clted research indlcating that with a firm, falr, responsive management style in asslsted housing, there was a higher level of volunteerism in maintaining the project, a measure this study was attempting to examine. 
The questionnalre, however, examined volunteerism as helpling others--tenants assisting tenants, e.g.

1 assist in helplng with my nelghbors, cerrands, cooking, escorting, etc.)

Some of the residents assist me when I require some hel p.

I spend some time volunteering in recreation programs in this bullding.

The personal observation of this researcher suggests a high level of volunteerism among tenants in elderly housing overall. It has been reported by others that in an estimated proportion of in-home care for seniors in this country, $80 \%$ comes from informal support systems (Weeden, 1985). Some of that informal support is highly visible in assisted-housing projects for elderly. Whether management style influences that volunteerlsm was not answered with this study.

\section{Eourth Hypothesis: Tenant Turnever}

Comparable data for verlfying tenant turnover was unavallable. Prlvate owners and operators do not compute turnover percentages, nor does thelr funding agency, the State Housing Division.

The public housing projects also do not keep percentages, and data would have to have been gathered by hand from back records. Information from the local HUD area offlice shows an increase in Bullding C's turnover, with a loss of 12 tenants in 1982 versus 15 tenants in 1984 (Wolfe, 
1984). Building $D$ was not included in that comparison report.

Tenant records for March 31, 1984, indicate zero vacancies on that day for Bulldings $A$ and $B$. Data provided by service coordinators show two vacancies on that day for both C and D (Greenough, 1984; Otness, 1984).

Some argument for partial support of this hypothesis might be garnered from the comparison of operating maintenance costs in the analysis of the fifth hypothesis. Tenant turnover is a factor that affects operating maintenance costs, and those costs were signiflcantly lower for Bullding $A$.

\section{Elfth Hypothesls: Cost Per Unit}

The fifth hypothesis is supported when using operating maintenance figures for the four projects. The cost differences between the private projects, $A$ and $B$, and the public projects, C and $D$, is large in terms of monthly cost per unit. An Intervening varlable included in that difference is union labor which causes the PHA projects to sustain higher malntenance costs. When the role of unlon labor was examined in the Urban institute studies it was found that those PHAs with higher percentages of union employees tended to have higher maintenance and operating costs, but conversely, had lower response time to malntenance requests (Sadacca et al., 1976). 
There is evidence that some pHAs nationally have reduced labor costs by contracting out malntenance of assisted projects or monitoring it closely. One PHA in Loraln, Ohio, offered their union employees the contracts resulting in continued employment for those employees plus labor and cost efficiencles for the PHA (Ashley, 1983).

So even with the union labor costs of Bulldings $C$ and D, the statistlcal differences in operating maintenance costs between Buildings $A$ and $B$ Indlcates support for the fifth hypothesis that Bullding A's monthly cost-per-unit would be lower than the three other bulldings included in this study. 
CHAPTER VII

\section{CONCLUSIONS AND POLICY RECOMMENDATIONS}

On the basls of prevlous studies, it was anticlpted that the five hypotheses tested in this present study would be supported. But the data provided support for only one of the hypotheses. Why did this occur? A number of considerations seem relevant. One of the hypotheses could not be tested because vacancy records were not avallable. The measures of tenant satisfaction with management nay not have been appropriate for use with elderly tenants since they were developed on and used with an entirely different population, families with chlldren. The questionnaire may have been too lengthy and the different scales appeared to confuse many of the elderly. Thus it would appear that these hypotheses were not given a good test--further studies are needed. Nevertheless, based on the review of the literature, Interviews with the other building managers, and personal experiences and observations $1+$ is possible to draw some conclusions and make some recommendations.

LLustrations_of Clted_Research_Becommendatlons

1. Managers of Senlor_Housing Projects

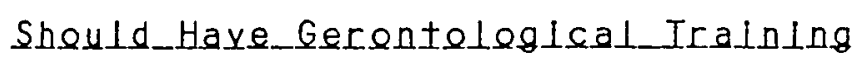

The administrator of Bullding $A$ had training in 
gerontology classes, had worked in a soclal service program for seniors, and had practicums in a mental hospltal. Those experlences were helpful when tenants talked about their "volces." The tralning helped keepelderly residents calm when another tenant was disruptive. Training provided the ablilty for the manager to recognize the problem when mentally handlcapped tenants were off their medications. This training knowledge saved dollars by preventing vandalism in a trashed unit by an upset tenant. Gerontological training allowed the administrator to recognize changes in older residents' behavior and to intervene before minor problems became serlous. The training provided an understanding of the older residents' need for conversation and when that need was merely social or of vital importance in preventing a serious situation.

\section{Managers of Senlor Hous Ing Should}

Have Service-Referra $\perp$ Sk $\perp \perp s$

Referral skills helped locate avallable housekeeping services for Bullding $A$ when tenants needed help maintalning units. Service-referral skills, by knowing who to contact and how, saved time in locating approprlate services. Being cognizant of tenants' amount and sources of income, friends, fam lly members, and other networks, also facllitated the identiflcation and linkage of approprlate services with tenants. 
Service referral obtained the help required to keep tenants in their apartments longer, helped them keep their units in shape, and created a more comfortable and hospitable living environment for everyone.

3. Managers Should Know_How to ReLate Properly

to and communlcate With Their older Tenants

Utilization of the administrator's training in human relations kept complalnts at a minimum in Bullding $A$ through careful explanations of the reasoning behind regulations, all apartment inspections, and other complex requirements for certification.

The administrator malntained friendly relations with the four tenants who had been evicted over the course of two and a half years from Bullding $A$.

This, perhaps, proved to be cost efficient as one of these tenants was subsequently evlcted from another bullding and returned to set a fire there. Knowing how to evict the problem, not the person, is a cost efficient management practice.

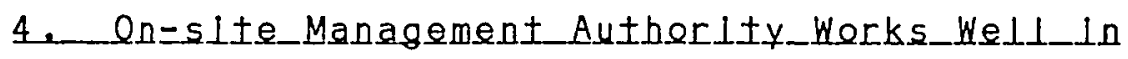

Impreving_communicatien_and_Reducing Iurnover.

The administrator kept regular working hours, five days a week. If emergencles arose ourlng the working day, they were handled at once. If emergencies arose during the manager's off hours, the live-in assistant had the authority 
to handle all maintenance problems. If people problems were beyond his capability, he called the manager in.

Being on-site facllitated the solution to maintenance emergencies, prevented more serious malntenance problems, and enabled tenants to go to someone on a regular basis to solve problems.

\section{Limltatiens to the Recemmendations}

The recommendations from the above were based less on evidence from the statistical data collected and analyzed in the study and more on the observations and partlal data collected from Interviews with other managers.

The observations of all the managers indlcated that turnover information is crltical to the success of a project. Less turnover means greater tenant satisfaction and contributes to the cost-effectiveness in each bullding. The study, however, was unable to collect turnover data which weakened the analysis of the hypotheses.

Also, the focus of the study was too wide. Whlle questions of locus of control and management style are valid, coupling these two theorles in one questionnaire weakened the research. The theorles would have been better served had they been developed separately.

The double questionnalre was long, and changed in both style and mode in its format, creating confusion on the issues for some older respondents. This confusion was 
evident from statements written on the instrument and also by conflicting responses to questions which measured similar components but were scaled in different directions.

The mall-out was an approprlate vehicle and produced a return rate of nearly 75\%. That older population surveyed by mall, however, might have understood the study better if personal interviews of a random sample of tenants from each of the buildings were used.

\section{Merlts of the study}

This study was signiflcant because it collected data from a newly opened project. Past research on management style was developed from projects already in operation.

Whlle the questionnaire results did not parallel the high rates of tenant satisfaction and volunteerism found in earller studies, there is some evidence that cost benefits are assoclated with management style.

\section{Policy Recommendations}

1. Implementatlon of Senier_Housing

\section{Management Gulde $\perp$ Ines}

Management firms vary in how they operate their bulldings. Nearly all require that thelr managers spend a great deal of time on paper work. Thls study recommends that managers be allowed the time to communicate more with 
tenants and paper work be relegated to an administrative back-up process.

\section{Comparable Salarles}

Another common problem in asslsted-housing nationally, is the low pald status of on-site management. There is some movement to improve the status of managers by requiring certiflcation. Locally, a communlty college is offering housing management training through its gerontological certificate program. Certification and training will not attract competent management without comparable salaries.

\section{Tenant Turnover Data}

Examining the reasons for tenant turnover is a vital source of information and that data is not presently being utilized. In senlor housing there always is attrition through death and frallty. When tenants leave for other reasons, an effort should be made to find out why and how to correct the problem.

An emerging vacancy rate in assisted-housing for seniors nationwide indicates the serlousness of the problem. Knowing why tenants are moving from a bulloing could be very useful to any owner/operator who is having difficulty keepling tenants. 
4. Euture_Besearch With_Housing Management

Researchers in the fleld should conslder finding ways to measure differences in management styles and behaviors. Collecting data is difflcult and proved to be a problem in this study. Finding ways to measure management style would be of benefit, not only for the emerging profession of managers, but for owners and operators who wish to implement those management style's guidelines into their projects.

For many housing agencles, management style is a preconceived plan developed from the top down. In the view of this researcher, it costs less to develop management around the needs of the older tenants as overall costs become lower through reduced turnover and vacancies.

\section{A Einal conclusion}

The final conclusion is based on the personal observations of the researcher in this field study. In retrospect, whlle the focus of the study would be narrowed and a smaller questionnaire would be used with personal interviews of a random sample of tenants from the four bulldings, the management style of Bullding A would remaln the same (see Appendix H). 


\section{REFERENCES}

Alston, Jon. 1973. "Age, Occupation and Life Satisfaction," Ihe Gerenteleglst, 13(1) 58-61.

Anderson, James R. and Sue Weldmann. 1979. "Development of an Instrument to Measure Residents' Perceptions of Residentlal Quality," (paper presented at International Conference on Environmental Psychology, Sarry, England), University of IIIInols.

Andreae, Antonla. 1978. Senier cltlzens Housing: Leca= tional censideration and Seclal Implications, Centre for Urban and Community Studies, Toronto, Canada.

Ashley, Robert. 1983. Prlyate Sector Invelvement wlth Publis Heusing. Lorain, Ohio: Lorain Metropolitan Housing Authority.

Astorlno, Robert L. 1981. "Public Housing Authorlty Should Be Less Dependent on HUD Subsidies for Operation," Journal ef Housing, 8, 203-204.

Bernsteln, Judith. 1982a. "Housing for the Elderly Requires Thoughtful Management," Journal ef Preperty Management, May/June, 18-20.

Bernsteln, Judith. 1982b. "Who Leaves--Who Stays; Residency Poll in Housling for the Elderly," Ihe Geronteleglst, 22(3), 305-309.

Brandt, Ann. 1979. "Relationshlp of Locus of Control, Environmental Constralnt, Length of Time in the Institution and 21 other Variables to Morale and Life Satisfaction of Elderly," Dissertation Abstract International, $40(12)$.

Brauer, Will lam. 1976. Greendale, Alexander and Knock, Stanley. (eds.) "Developing Sensitive Management," Housing Cests \& Heusing Needs, New York: Praeger Publishers.

Bruning, James L. and B. L. Kintz. 1972. Computatienal Handbeak ef Statistles, 2nd Edition, Glenview, IIIInols: Scott, Foresman \& Co. 
Butler, Alan and Christine Oldman. 1983. "Greater Clarity Needed on Rule of Sheltered Housing Wardens," Housing, Feb., 19(12), 16-28.

Carp, Francis. 1966. A Euture for the Aged, Austin, Texas: University of Texas Printing Division.

Cartee, Charles P. 1981. "Professlonal Management of Public Housing," Jeurnal ef Preperty Management, July/Aug., 217-221.

Cartee, Charles P., Alan Butler, and Christine Oldman. 1983. "Greater Clarity Needed on Rule of Sheltered Housing Wardens," Housing, 19, 16-20.

Cedarleaf, Emily. 1985. Personal Contact. Homebullders Association of Metro-Portland, Portland, Oregon.

Chang, Betty L. 1978. "Generallzed Expectancy, Situational Perceptions, and Morale Among Instltutionallzed Aged," Nursing Besearch, 27(5), 316-321.

Cohen, Sheldon, Myron Rothbart, and Susan Phillips. 1975. "Locus of Control and the Generality of Learned Helplessness in Humans," Journal of Persenality and Seclal Psychelegy, 34, 1049-1056.

Commission on Housing. 1982. The Repert of the President's commission on Heusing, Washington, D. C.: Library of Congress.

Conrad, Joseph. 1970. "Getting Involved in Low-Income Housing", Jeurnal ef Property Management, 35(5), $234-236$.

Dillman, D. A. 1978. Mall and Telephene Suryezs: The Iotal Deslon Methed, New York: John Wiiey \& Sons.

Edwards, John N., and David Klemmack. 1973. Hesllck, Irene (ed.) "Correlates of Life Satisfaction" in Lmperlal Studies in the Psychelegy and Seclelegy ef Aglng, New York: Harper \& Row.

Fawcett, Gayle, Davld Stoner, and Harold Zepelin. 1980 . "Locus of Control, Perceived Constraint, and Morale Among Institutional ized Aged," Lnternatienal deurnal of Aging and Human Dexelerment, 11(1), 13-23.

Fitzgerald, Robert J. 1977. "The Publ l c Housing Manager: No Place For A Loner," Journal ef Rreperty Management, $43(3), 117-120$. 
Fitzgerald, Robert J. 1979. "Managing Housing for the Elderly," Leurnal ef Property Management, April/May, PP. 68-69.

Francescato, Guido, Sue Weldmann, James Anderson, and Rlchard Chenoweth. 1979. Besldent Satisfactien in HUD = Assisted HousIng: Deslgn \& Management Eactors, HUD Office of Pollcy Development \& Research, Washington, D.C.

French, Glenn. 1977. "Reducing the Risks in Subsidized Housing," Jeurnal ef Preperty Management, May/June, $122-124$.

Frledman, Joseph, and Daniel Welnburg. 1982. The Ecenemles of Housing Vouchers. New York: Academic Press.

Fuchs, Paul. 1977. "Service for the Elderly are the key to a Successful Minneapolis Housing Program," Leurnal ef Housing, 4 .

Fuerst, J. S. 1977. "Subsldized Housing: Amateurs Need Not Apply," Jeurnal ef Rrorerty Management, 42(5), 261 264.

Galner, William. 1983. "Subsidized Housing Production: Profiting From Past Errors," Leurnal of Houslng, 4(3), $77-79$.

Garver, Perry. 1982, 1983, 1984, 1985. Personal Contact. Manager, Bullding B. Guardian Management Corp., Portland, Oregon.

Glass, D. C., B. Reim and J.E. Singer. 1971. "Behaviorlal Consequences of Adaption to Controllable and Uncontrollable Nolse," Leurnal ef Experlmental Secial Psychelog7, (7).

Glass, D. C., J. E. Singer, and L. C. Frledman. 1969. "Psychic Control of Adaption to an Environmental Stresses," Leurnal of Persenality \& Seclal Psychelegz, $12(9), 200-210$.

Glass, David C., J. E. Singer, H. S. Leonard, D. Krantz, D., S. Cohen, and H. Cummings. 1975. "Perceived Control of Adversive Stimulation and the Reduction of Stress Responses," Jeurnal of Persenallty, 41(4), 577-598. 
Green, Isaac, Bernard Fedewa, Charles Johnston, William Jackson, and How ard Deardorff. 1974. Housing fer the Elderly: The Deyelepment and Deslgn Rrocess, New York: VanNostrand Reinhold Co.

Greenough, Judl. 1984. Personal Contact. East Area Director, Housing Authority of Portland.

Grooms, Albert. 1979. "The On-Site Manager: A Key Link in the Chain of Communication," Jeurnal ef Preperty Management, Jan/Feb., 4-6.

Hellebrandt, Frances. 1980. "Aging Among the Advantaged: A new Look at the Stereotypes of the Elderly," Ihe Geronteleglst, 20(4), 404-417.

Heumann, Leonard and Duncan Boldy. 1982. Houslng fer the Elderly, New York: St. Martins Press.

Hooker, Carole. 1976. "Learned Helplessness," Seclal Work, May, 194-197.

Howel1, Joseph T. 1984. "Project Syndication - How it Works," Jeurnal ef Houslng, 41(4), 105-109.

Hughes, W. D. 1976. Greendale, Alexander and Krock, Stanley (eds.) "How to Utlilze and Improve Federal and State Housing Programs for the Elderly," Hellsing Cests and Heusing Needs, New York, N.Y.: Praeger Publishers.

Hunter, Kathleen, Margaret Linn, Rachel Harris, and Theodore Pratt. 1980. "Discrimination of Internal and External Locus of Control Orlentation in the Elderly," Research on AgLing, 2(1).

Huttman, El izabeth. 1977. Heuslng and Seclal Serylce for the Elderly, New York: Praeger Publishers.

IREM, Greater Metropolitan Chapter of. 1970. "A Recommndatlon for the Management of Low-Income Housing," Jeurnal ef Preperty Management, 35(4), 170-175.

Isler, Morton, Robert Sadacca, and Margaret Drury. 1974 . Keys To Successful Heuslng Management, Washington, D.C.: Urban Institute.

Jackson, Karen. 1984, 1985. Personal Contact. Servlce Cooidinator, Housing Authorlty of Portland; Portland, Oregon. 
Kabat, Cynthia. 1980. "Life Satisfaction and Locus of Control in Golng Old and Old, Old Adults," DLssecta= tion Abstracts lnternational, $41(3)$.

Kerlinger, Fred. 1973. Eeundatlens ef Behavleral Research, New York: Holt, RInehart and Winston.

Kolodny, Robert, Richard Baron, and Raymond Struyk. 1983. Ihe $\perp$ hslder's Gulde to Managlng Public Heuslng, Washington, D.C.: U.S. Department of Housing and Urban Development, Offlice of Pollcy and Urban Development.

Kozma, Albert \& M. J. Stones. 1983. "Predictors of Happlness," Jeurnal ef Gerentolegx, 38(5), 626-628.

Langer, Ellen J., and Edith Rodin. 1976. "The Effects of Cholce and Enhanced Personal Responsibllity for the Aged: Field Experiment in an Institutional Setting," Jeurnal ef Rersenallty \& Seclal Psłcheleg7, 34(2), 191-198.

Lawton, M. Powell. 1975. Planning and Managlng Housing for the Elderly, New York: John Willey \& Sons.

Lawton, M. Powell. 1980. Enxirenment and Aging, Belmont, California: Wadsworth, Inc.

Lawton, M. Powell, and Sally L. Hoover. 1981. Cemmunity Heldsing Chelees for llder Amerlcans, New York: Springer Publishing.

Lefcourt, Herbert M. 1976. Lecus ef centrel = Current Irend in Iheery and Research, New York: John Wlley \& Sons.

Ling, Timothy, and Robert Sadacca. 1975. A Compesite Begressien Medel ef Public Heusing Management, Working Paper, The Urban Institute, Washington, D.C.

Liston, Robert. 1974. Ihe Ugl\# Ralaces = Heusing $1 \mathrm{n}$ America, New York: Franklin Witts.

Loux, Suzanne, and Robert Sadacca. 1975. Changes In Management Perfermance in Publis Heuslng, Working Paper, The Urban Institute, Wastington, D.C.

Loux, Suzanne, and Robert Sadacca. 1977. Preliminary Analys $\perp s$ ef changes in Perfermance at large $P u b \perp \perp c$ Heusing Agencies Erom 1273 te 1276, Working Paper, The Urban Institute, Washington, D.C. 
Loux, Suzanne B., and Robert Sadacca. 1980. Comparisen ef Public Housing Ienant Characterlstics: $1976=1279$, Working Paper, The Urban Institute, Washington, D.C.

Matheny, Richard. 1976. "Challenges of Public Property Management," Jeurnal ef Preperty Management, 41(5), 216-217.

Meehan, Eugene J. 1983. "Is There a Future For Public Housing," Journal of Housing, 40(3), 73-76.

Mercer, Susan, and Rosalee Kane. 1979. "Helplessness and Hopelessness Among the Institutionalized Aged," Hea Lth \& Seclal Werk, 4(1), 90-116.

Murray, Joseph. 1972a. "Managing Federally Assisted Housing: Problems or Opportunities," Jeurnal ef Property Management, 37(1), 4-8.

Murray, Joseph C. 1972b. Managing Low-Cost Nonprofit Housing," Jeurnal ef Preperty Management, 35(1), 8-13.

NAHRO B ibliography. 1984. "50 Years of Housing Pollcy," Journal of Housing, $41(1), 20-22$.

National Center for Housing Management. 1974. Housing for the Elderly: The en=Slte Manager's Resource Beok, Washington, D.C.

National Center for Social Pollcy, Inc. 1979. Managlng Housing \& Services for the Elderly: A Besource Book, Wash., D.C.: National Center For Houslng Management.

National Corporation for Care of old People. 1973. Heusing in Betirement, London.

National Housing Law Project. 1982. The Subsldized Housing Handbook: How to Provide, Preserve and Manage Housing for Lewer $=1$ nceme Reople, Berkley, California: National Housing Law Project.

Nehrke, Milton, and Gunals Relmanes. 1978. "Locus of Control Among Institutional lzed Males and Community Dwelling Males," Paper read at the Gerontologist Soclety's 31 st Annual Meeting.

Nenno, Mary K. 1982. "The President's HUD Budget: A Blueprint for the Future," Jeurnal ef Housing, 39(2) 43-50. 
Nowlcki, Stephen. 1974. The Adult Nowlckl=Strickland Interna $\perp=E x t e r n a \perp$ centrel Scale (ANS-LE): College \& Nen= cellege Eerms. Courtesy of Stephen Nowlckl, Department of Psychology, Emory University, Atlanta, Georgla.

Nowlckl, Stephen, and Marshall Duke. 1973. "A Locus of Control Scale for Non-college as Well as College Adults," Lournal of censulting \& clinlcal Psycholegx, $40(1), 183-154$.

Onibokun, Adipoju. 1974. "Management and the Livability of Publlc Housing," Jeurnal ef Preperty Management, $39(3), 120-123$.

Oregon State Housing Division. 1984. Section 8 Heusing Management Handbeok.

Oregonian, The. 1980, September 10. Landlord's novel approach with tenants fosters reclprocation, page B4.

Ostrowski, Elalne. 1984. "Managing Publlc Housing: The Impact of the 80's," Jeurnal ef Heuslng, 41(2), 40-42.

Otness, Randi. 1982, 1983, 1984, 1985. Personal Contact. Service Coordinator, Housing Authorlty of Portland, Portland, Oregon.

Parker, Rosetta E. 1984. "The Future of Elderly Housing," Journal of Preperty Management, May/June, 12-16.

Phares, E. J. 1968. "Differential Utllization of Information as a Function of Internal-External Control," Journal ef Personality, 36(4), 648-662.

Phares, E. J. 1971. "Internal-External Control and the Reduction of Reinforcement Value After Fallure," Jeurnal ef Consulting \& clinical Psłcheleg*, 37(3), $386-390$.

Pollkoff, Alexander. 1978. Heusing the Poor: Ihe Case fer Herelsm, Cambrldge, Massachusetts: Ballinger Publishing Co.

Porco, Carmen. 1980. Personal Contact. Oregonlan Newspaper New servlce Reprint on Carmen Porco, September 10,1980 . Section B, P. 4 . 
Ralston, David A., and Cynthla A. Ralston. 1933. "How to Select an On-Site Manager," Jeurnal ef Preperty Management, July/Aug., 10-13.

Reakes, Jullannl T. 1980. "The Effects of two Appropaches to Assertive Tralning on Self Esteem, Assertiveness, Locus of Control and Life Satisfaction with Women," Dissertation Abstracts Internatienal, $40(7)$.

Regnier, Victor, and Thomas Byerts. 1983. "Applying Research to the Plan and Design of Housing for the Elderly," in Housing fer a Maturing Pepulation, Urban Land Institute, Washington, D.C.

Reld, David W., Gwen Haas, and Douglas Hawkings. 1977. "Locus of Desired Control and Posltive Self Concept of the Elderly," Leurnal ef Gerontelegy, 52(4), 441-450.

Richter, Curt P. 1959. "The Phenomenom of Unexplained Death in Anlmals and Man," In Ihe Meanlng ef Death, New York: McGraw HIII.

Rose, Edgar A. 1978. Heusing for the Aged, Westmead, Farnborough, Hampshire, England: Saxon House.

Rotter, Julian B. 1954. Seclal Learnlng \& $\mathrm{S} \perp \ln i c a \perp$ Ps $=$ cholegy, Englewood Cliffs, New Jersey: Prentlce Hall.

Rotter, Jullan B. 1966. "Generallzed Expectancies for Internal Versus External Control of Reinforcement," Psłchologlcal Menegraphs: General and ApRlied, American Psychological Assoclation, 8(1).

Rotter, Jullan B. 1971. "External Control and Internal Control," Psycholegy Ioday.

Rotter, Jullan B., M. Seman, and Liverant. 1962. "Internal vs. External Control of Relnforcements: A Major Varlable in Behavioral Theory," in Declsiense Values. and Grouns, Vol. 2, N. F. Washbourne (ed.), London.

Sadacca, Robert, Morton Isler, and David Carlson. 1976. "Effective Subsldized Housing Practices," Jeurnal ef Property Management, $41(5), 210-214$.

Sadacca, Robert, and Suzanne D. Loux. 1978. Imprexing Publis Heuslng Ihrough Management: A Iechnlcal Besert, Working Paper, The Urban Institute, Washington, D.C. 
Sadacca, Robert, Suzanne Loux, and David Carlson. 1978. Impreving Pub lic Heuslng Ihrough Management, Working Paper, Urban Institute, Washington, D.C.

Sadacca, Robert. 1981. Personal contact.

Sanzotta, Donald. 1979. Ihe Manager's Gulde te Interper= senal Relatiens, New York: ANACOM.

Schenk, David. 1984, 1985. Personal Contact. HUd Occupancy Speclalist, Washington, D.C.

Schulz, Rlchard. 1976. "Effects of Control and Predictabllity on the Physlcal and Psychological Well-Being of the Institutionalized Aged," Journal ef Persenallty and Seclal Esychelogx, 33(1).

Seligman, Martin E. P. 1968. "Chronlc Fear Produced by Unpreditable Shock," Journal ef Cemparatlye and Physlelegical Psychology, 66, 402-411.

Seligman, Martin E. P. 1975a. Helplessness en Depresslon Development and Death, San Franclsco: W. H. Freeman.

Seligman, Martin E. P. 1975b. Learned HeLRLessness, San Franclsco: W. H. Freeman \& Co.

Seligman, Martin E. P., and Steven F. Maler. 1967. "Fallure to Escape Traumatic Shock," Journal ef Experimental Psychelegy, 74(2), 1-9.

Sellgman, Martin E. P., S. F. Maler, and J. H. Geer. 1968. "The Allevlation of Learned Helplessness in the Dog," Journal ef Abnermal Psycholeg7, 73(3), 256-262.

Sellgman, Martin E. P., S. F. Maler, and R. Solomon. 1969. "Unpredictable and Uncontrollable Aversive Events," in

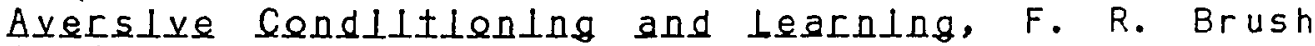
(ed.), New York: Academlc Press.

Simmons, Earl. 1984. Personal Contact. National HUD Occupancy Specialist, Washington, D.C. Malled national summary of public housing vacancy rates.

Simmons, Samuel J., and Norman V. Watson. 1973. "Focus on Assisted Housing," Leurnal ef Prepertł Management, 38 , January/Feb., 6-9.

Skinner, B. F. 1974. About Behaylerlsm, New York: Random House. 
Slavik, J. Ronald. 1981. "Senlor Housing: Practical Innovations," Jeurnal ef Predert¥ Management, July/Aug., $229-232$.

Sloan, Martin E. 1984. "1983 Act: A Leap Backward," Jeurnal of Heusing, $41,112-113$.

Soldo, Beth J., and Herman B. Brotman. 1981. "Housing Whom" in Communitz cholces for lider Americans. New York: Springer Pub.

Stegman, Michael A. 1980. "Trouble for Multi-Famlly Housing," in eccaslonal Papers in Housing \& cemmunity Affairs, Vol. 2, HUD, Washington, D.C.

Struyk, Raymond. 1980. A New System Eer Public Housing: Salyaging A Natlonal Resource, The Urban. Institute, Washington, D.C.

Struyk, Raymond, Sue A. Marshall, and Larry J. Ozanne.

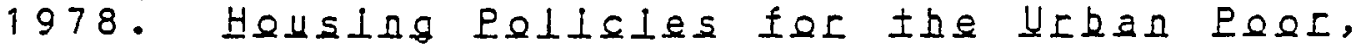
Washington, D.C.: The Urban Institute.

Struyk, Raymond, Neil Mayer, and John A. Tuccillo. 1983. Eederal Housing Policy at President Beagan's Midterm, Washington, D.C.: Urban Institute Press.

Thorndike, Robert. 1982. Data Collection and Analysls, $N \in y^{\prime}$ York: Gardner Press.

U.S. Department of Housing \& Urban Development. 1979. Characterlstles ef the Elderly, Washington, D.C.: U.S. Government Printing Office.

U.S. Department of Housing \& Urban Development. 1983. U.S. Housing for the Elderly, Offlice of Policy Development and Research.

U.S. Department of Housing \& Urban Development. 1984. Eact Sheet $=$ H.U.O. Assistance to the Elderly, Washingion, D.C.: Office of Policy Development and Research.

Warner, Katherine P. 1983. "Demographics and Housing," in Houslng for a Maturing Pefllatien, Washington, D.C.: Urban Land Institute.

Weeden, Joel. 1985. "The housing Compendium," Generations, Spring. 
Weldmann, Sue, and James Anderson. 1980. Plannlng for Change in Multl=faml1* Heusing, Paper presented at People-Manmade Environment, Sidney, Australla; University of IIIInols.

Welcher, John C. 1980. Heusing: Eederal Pelicles and Pregrams. Amerlcan Enterprlse Institute for Public Pollcy Research, Washington, D.C.

Wolfe, Betty: 1984. Personal Contact. HUD Occupancy Speciallst, HUD area office, Portiand, Oregon.

Wolk, Stephen. 1976. "Situational Constraint as a Moderator of the Locus of Control-Adjustment Relation-

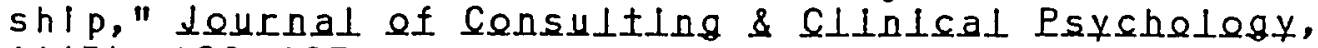
$44(3), 420-427$.

Wolk, Stephen, and John Kuntz. 1975. "Posltive Adjustment and Involvement During Aging and Expectancy for Internal Control," 43(2), 173-178.

Wollock, Richard G. 1977. "Turnaround Handbook for Problem Properties--Resldent Communication," Jeurnal ef Preperty Management, 42(3), 126-128.

Woodward, John, and Tricla Wakefield. 1982. "An In-Service Court for Housing Wardens," Housing, 18(11), 12-13.

Wye, Chrlstopher, John Pickering, and David Kanlnsk. 1980. "The Problems of Financlally Troubled Subsldized Projects," in lecaslenal Pagers in Heusing \& communlty Affairs, 12 .

Zals, James P. 1984. "Administering Housing Allowances," In Heusing Yeucher fer the Peer, Raymond Struyk and Marc Benedict, Jr. (eds.), Washington, D.C.: The Urban Institute.

Zais, James P., Raymond Struyk, and Thomas Thibodean. 1982. Heusing Assistance fer Older Americansi Ihe Beagan Prescrlption, Washington, D.C.: Urban Institute Press.

Ziegler, Michael, and Davld Reld. 1979. "Correlates of Locus of Desired Control In Two Samples of Elderly Person: Community Resldents and Hospltalized Patlents," Jeurnal of censulting and cldnical Esycheleg7, 47(5), 977-979. 
APPENDIX A 


\section{Subsidy housing 'going begging'} BY STEVE JEMNING

II Jares Schaiver seemed a tive coofused ose coutl underriod athy.

la 1980. Schaicer's Clay Towe aperterer buildiag in downtows Par. and opened to venos insust sucoser. Tre iederilly resi-subsidized oneber roosen units were sanked up oy spaces buney tenasts is a mane of duys, with manters choosing meinly trom the top of 2 aiving list that had begug formin evea belore the building was completed Now. almost etree yenrs later. cent-subsidized apsrument bouses. 20

He is offering $\$ 100$ cash bonuses in search of tenants for the Lexington

the sory the tells is subsuovially differ. eal Bot dew projecs tave bees avaif sole for ocespascy sidec hate ha yer. Both have large vacast; facork

And Schatzer is wopdeting why, ss miny be the developers of otber rearsered for low-income resideats.

There's beth so waidag lis this time." said Schaitzer. probably the sule's mapr pnvale developer of sutos dized reaul bouspe. is a recen

Wits the building oped fally three months terete ure about 20 vacancia in Schoitzef's St-uart Lerinetoo ipar meat house as 1125 S.W. I23 Ave.

The Part Tower. formerly the P2Havilued Howel before Schurcer purchased it 200 invested 28.5 milliag is 162 uasts reated or reserved at her re port Muagers of the 711 S.W. Salmos St buildiog bave beed seckiog tranas since mud-Dectober.

Sebajarer the comomisrioned acous Averusiag proclarimat the are naes of expenovely tefurbiched builo ines. He is oftenge 5100 crish boouses seereb of leans for the Lericrion.

"We thidk it may lake 90 days. sime for the buildines Developers of rest-sabsidized bous ing under the federd Depertacer of Housang and Utheo Devetoomert's Soedoo 8 protram essoat afford to wit wuch loneer tbas 90 days io actieve full occuperey in thers oujldigge. For the firs ithree worths. FUD will gursantere revenue equal to what would be arsed is 80 percent of the building were ocenpied Afur that rear subso dies are recent

HUD officiels set the rated sute for each propect using local berket rests is yardrock. Qualified low-income elderty of physically dissbied teanas pay no mare then 30 percent of their posthy insome in rents wh bectos 8 picking np the regeinde. The Leridran's perthit reass which tave been fixed by

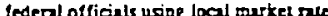

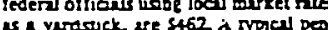
so ycrack are st62 A typical peos. Do mare then 5100 per monet for

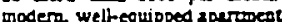

There ste il lear five othe PanTectiog 5 renovation projects in vious suges of developmeat, wo pote Park Tower and the Leriegan

If I were them- Schriver gid of be developers. Tra be pleaty concernod about the vacancy inctor."

Althougb the proeram is trowing to ircer. Section 8 developers like schater ere beine tur by a gesen acreuse to a ll residepanl vacascy level rougat on by ancerployment according to Ko Stil. Sexrte

The bigh vacang in the Don-subsoThed murket his bad a motiente eftren

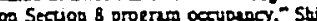
sid.

And tuis problew is occurite even antb recesty

The people who go inco wese build5 Es me sout $\$ 200$ to $\$ 100$ pet wonth. - Sctnilser sid. - But you could be making is muth is $\$ 1.000$ a mogh ad qualify for 5 ersiog \&

Theign Sobrson, resul dimecor tar the Portans Hounaz Authonty. seid reeestly that there were sore then sidued hounge wistong ties

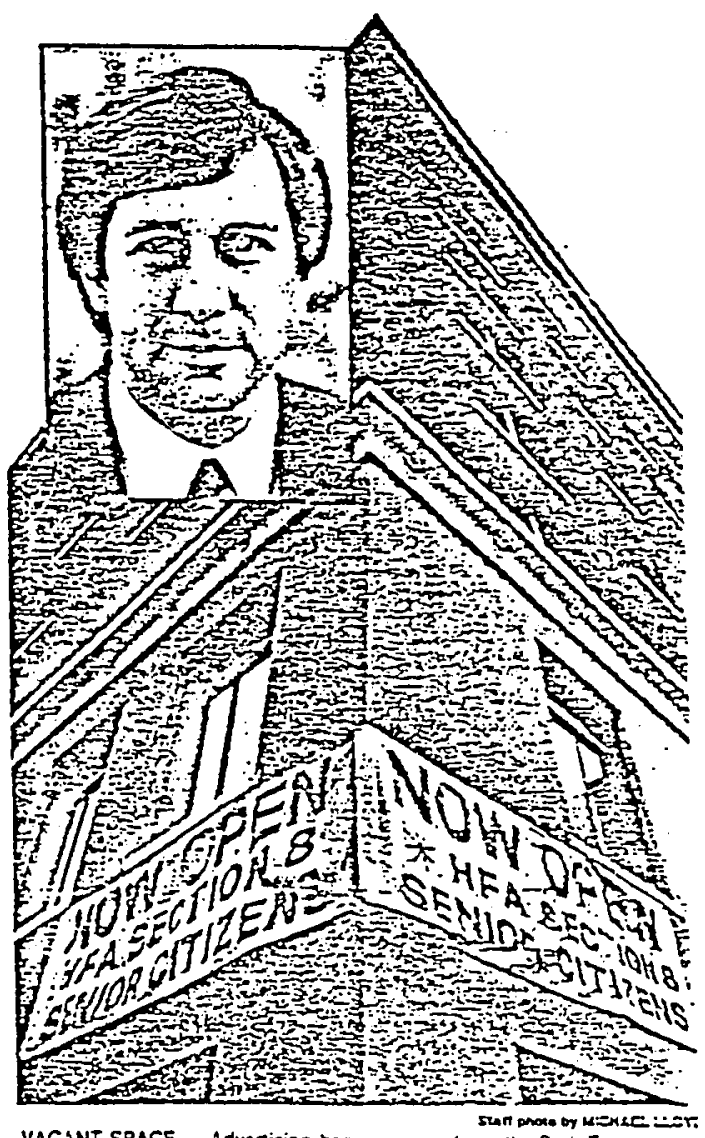

VACANT SPACE - Advertising banners wave trom the Park Tower apar ment nouse in downtown Portland. Developer Jordan Sennicer. inset, sait tenant interest in the rent-subsidized propect in which he invested $\$ B$. million. has been surprisingly sort.

This tome of yeer It's berder for elderts peopte to get yound jobero diculsog that there is a bonomiess wet We expect mote movemeat of low-acome, etcerly people "Schnis.

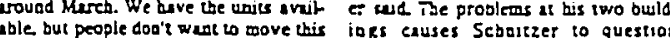
ame of year."

With Pontand area viancy rates up full percenufe poad in tbe lest yesp. lower reals and more concessions to teans my be encoungict some bay. dized renul bouga. ons causes Scbaizzef io questios acrually exise

Howere. Johneos seid we hishraciog.

There's sill a great oeed for redi rubodized bousag," she sad 
APPENDIX B 
SERR TE:INUIT,

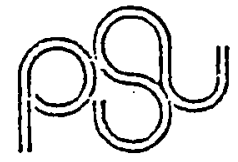

YOLR BUILDING IS 3EING INCLUDED IN A RESERRCi STUPV OF

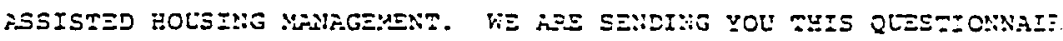

$::=\div: \because$ $\therefore \because \cdots$

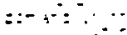
$\because \therefore-\therefore$

$\therefore$ $\therefore . .$.

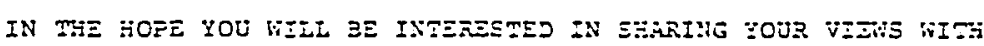
THE SESERTC: ZEM:.

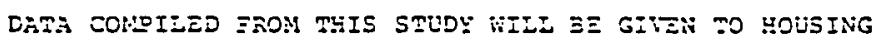
DEVELCZERS IN ORLER TO ENASIE THEM TO IYZRC:E THEIS SERVICES TO

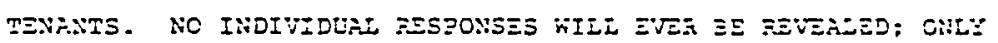

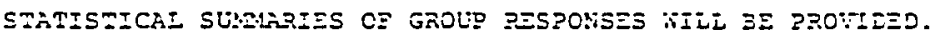

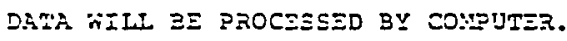

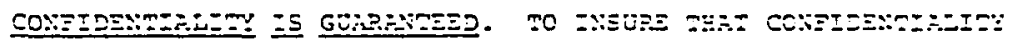

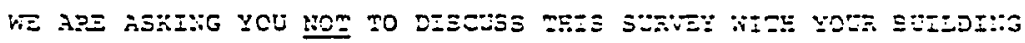

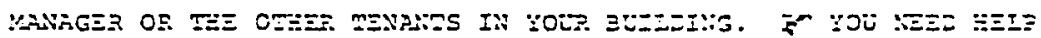

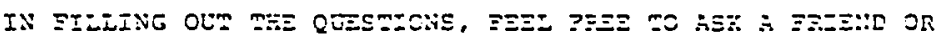

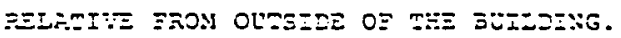

IN ORDEA ZCZ T:E IXZOP:EION 00 EE

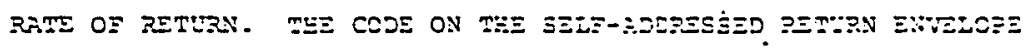

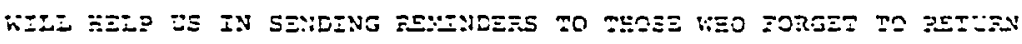

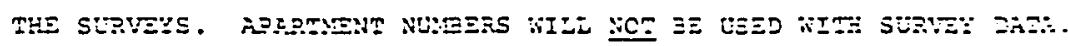

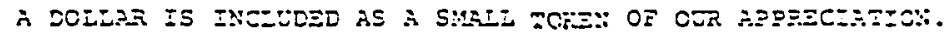

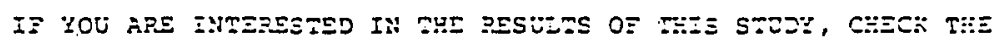

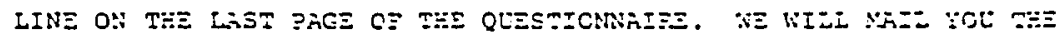

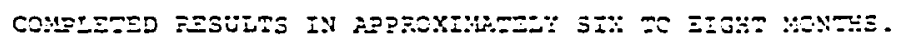

STXCEPEZY, .

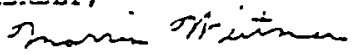

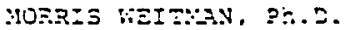

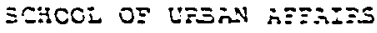


APPENDIX C 


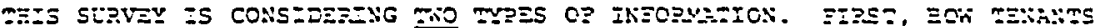

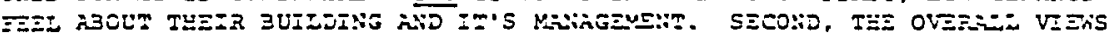
OF ADUL:S IN הJSISTED EOUSING PROGRAMS.

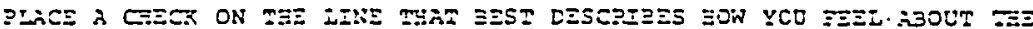
DE:OLITNG QUESTIONS.

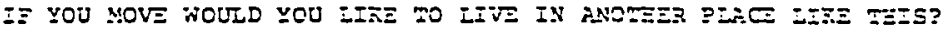

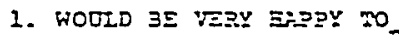

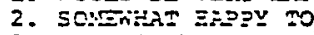

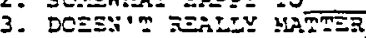

4. SOMDinisiz ENergoy mo

5. hOULD $3 E$ VERY TREA

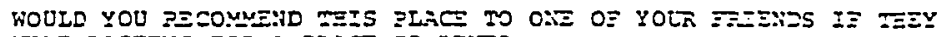

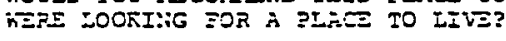

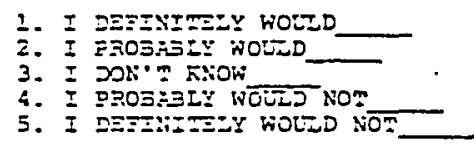

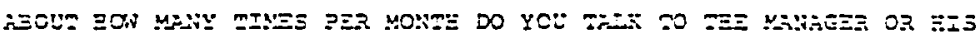

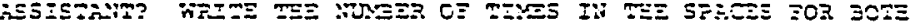

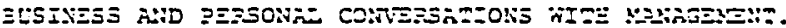

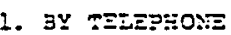

\section{UST:ES5}

2. IX $\mathrm{YZE}$ OFZICE

IEx NON:3

IEล Mo::T:

gEzeON=I

3. IN vOUS JONE ?ES :ONTS

․ $3 Y$ I $:=2=3$

IER MON:E

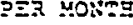

PER , YOSTE

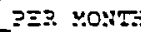

?ER MอNT:

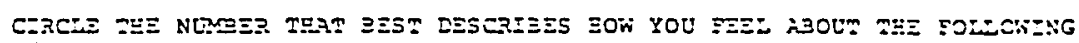
QUE⿰氵ICNS.

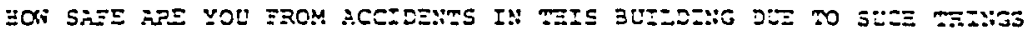

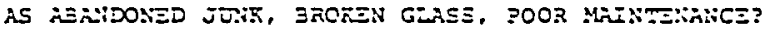

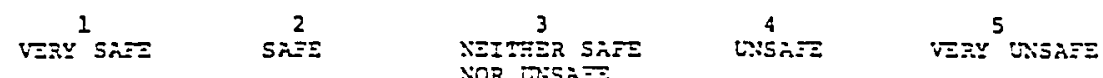

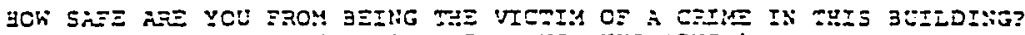

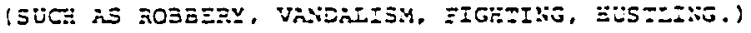

\begin{tabular}{|c|c|c|c|c|}
\hline 2 & $\ldots$ & $3^{3}$ & $\therefore$ & $5 \ldots$ \\
\hline 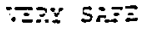 & $3: \Sigma \equiv$ & 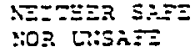 & $\therefore: 3 r: Z$ & 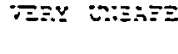 \\
\hline
\end{tabular}


2

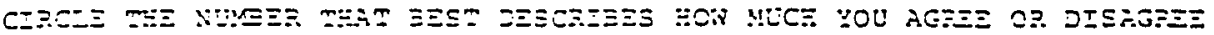

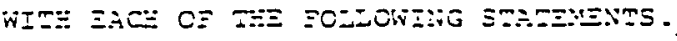

\begin{tabular}{|c|c|c|c|c|}
\hline 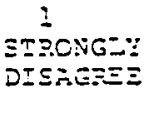 & 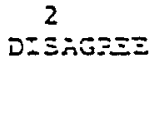 & 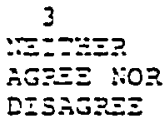 & $\therefore \stackrel{4}{a}=\Xi \Xi$ & 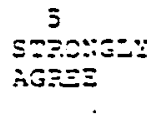 \\
\hline
\end{tabular}

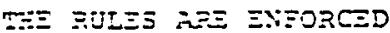

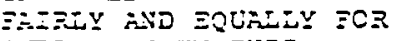
EVEE:3CDY IN

BUTZJมง

1

2

3

45

I WOULD FAT:ESR HVIV NO

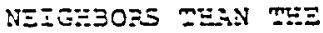
XETU:OEOSS I EAVE NOW

I GEm ALCNG WEت TIITE

TEE MiNAGEVE:Im

\section{3}

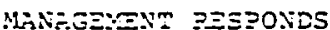

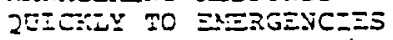

IN THE SUIUJAN.

1

2

3

4

1

MELFGEYENT RESFONDS IN

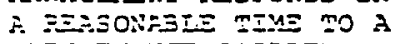
Y.IA:

I

2

3

; $\quad \vdots$

TEZ NTLES FOOUm WEAm I

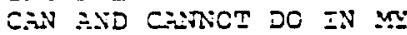

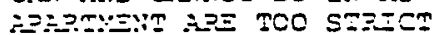

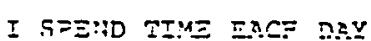

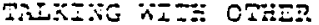

n:ละDEn:z

I SEE:T II:E ERC:

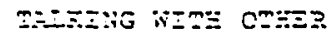

PESTIENTS

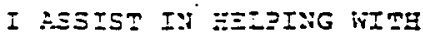

MY NEZG:ECRS. (ERZANDS

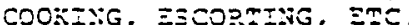

SON: CE THE RESTZENTS

ASEIST ME WREN I BEOUIRE

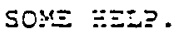

I SEZND SONE TIME

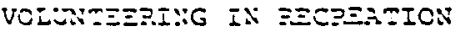

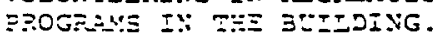

1

2

3

; $\quad \Xi$

EOR G:E ENOL:M CE MONEY

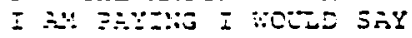

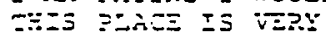

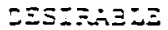

2

2

2

3

3

45

1

2

2

3

$\Xi$

2

.


CZSCE TEE NUEER ON EACE IISE TEST ZEST SUPDOSTS YOUR VIJWS ON TEZ ZOZTUIING STATENENI.

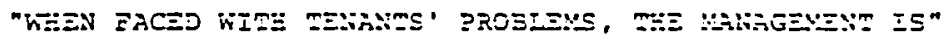

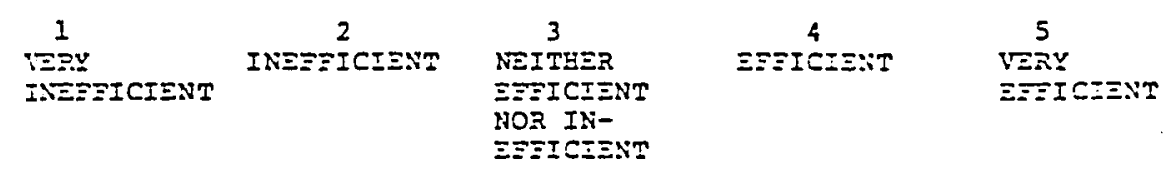

\begin{tabular}{|c|c|c|c|c|}
\hline $\begin{array}{l}1 \\
\operatorname{lag} \\
\text { COOZERATIV }\end{array}$ & COOPERATIVE & $\begin{array}{l}3 \\
\text { NEIME:R } \\
\text { COOPERATIVE } \\
\text { NOR UNCOOP- } \\
\text { ERAIVI }\end{array}$ & UNCOUPESATIVE & $\begin{array}{l}5 \\
V \equiv \sum x \\
\text { U:COOEESATIVE }\end{array}$ \\
\hline
\end{tabular}

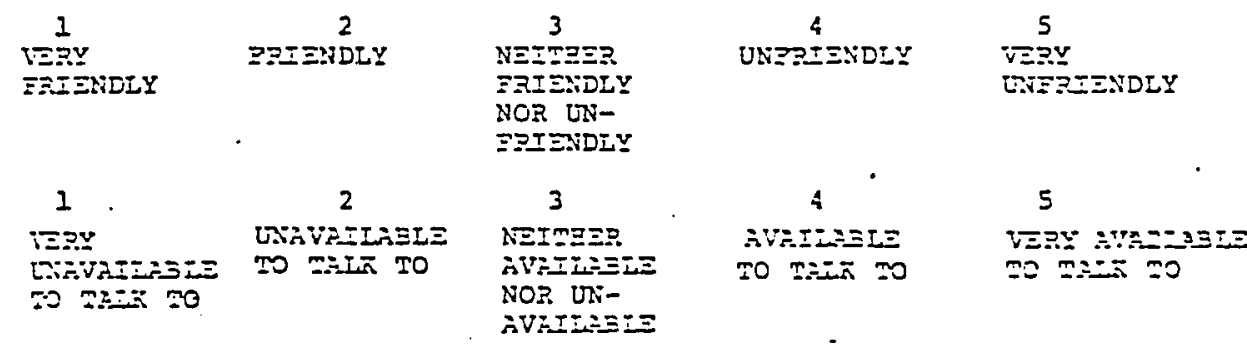

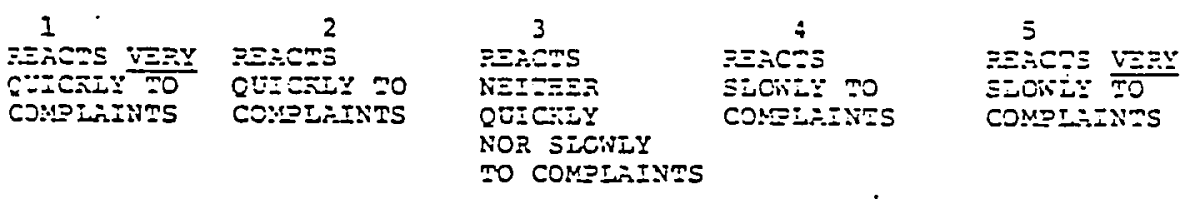

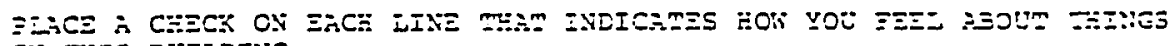
IT TES BUITDING.

\begin{tabular}{|c|c|c|c|c|}
\hline 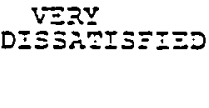 & 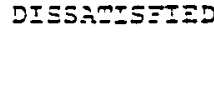 & 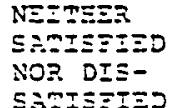 & 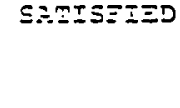 & 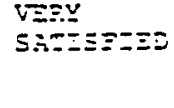 \\
\hline
\end{tabular}

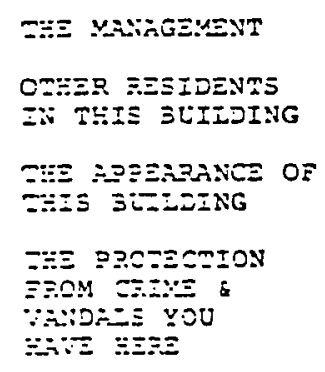




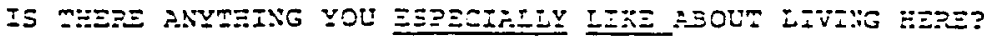

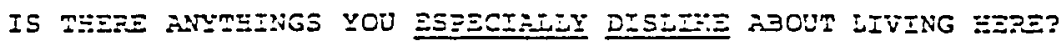

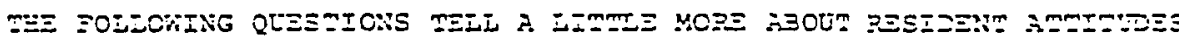

iN ras

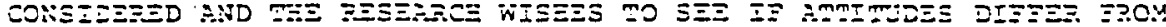

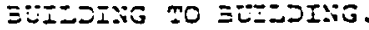

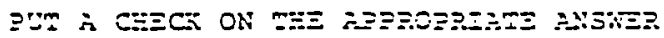

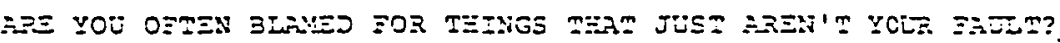
$\because \equiv \equiv() \mathrm{NC}$

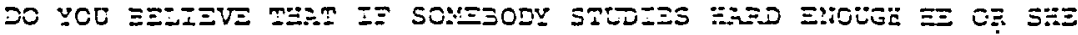

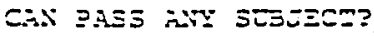

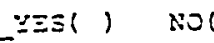

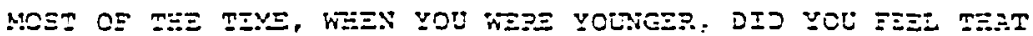
GETIING GOOD GEIDES MEANT A GEEAT DEAL TO YOU? Yas $(1)$ No:

LO YOU $\equiv \equiv \equiv$ T:

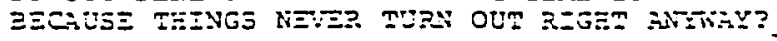
$\because \Xi \equiv !, \quad$ No!

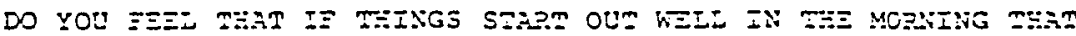
II'S GOING TO $\equiv \equiv$ iे GOOD DAY NO MITTER IT:ES YOU DO? yEs() $\mathrm{No}$

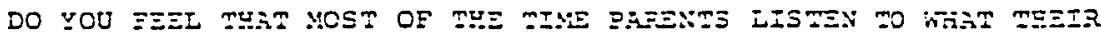
CEILDEEN HEVE TO SEY? YEs() No(

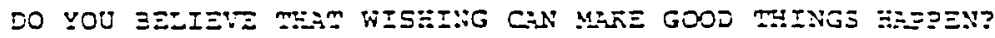
yEs() nol הEN

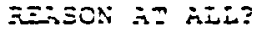
$\because \Xi 5 i$, ioi

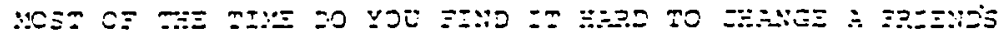

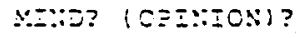

Yミs!： : :0i




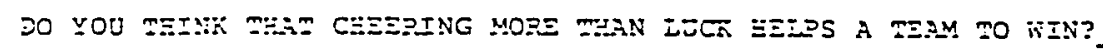
vasi) no(

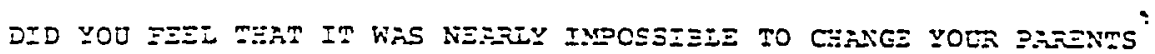

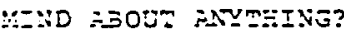

vast, nol

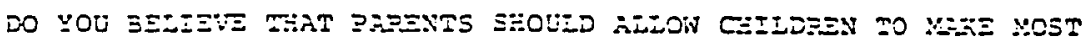
OE TEEIS CWN DECISIONS? vas $1, \quad$ :01

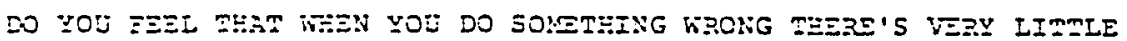
OU CiN DO TO

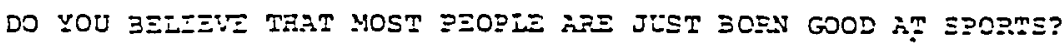
Yas, $)$ vol

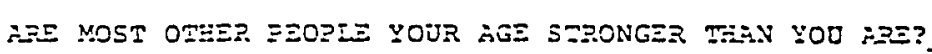
Yes, Nol

DO YOU EEEL M:AT ONE OF TLE EEST hAYS TO EMTDLE YOST PROSLENS IS

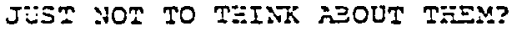
yes() No(

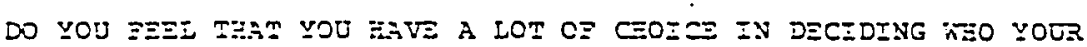
EZIENiDS in:? vasi, nol

IE YOU EIND A FOUR IEAF CLOVER, DO YOU BEIIEVE TEET II MIGEM JEING

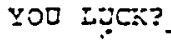
YEs() Nol

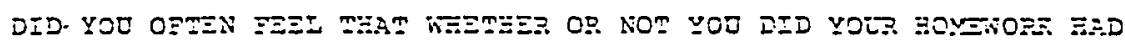

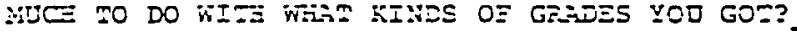
$y=3$, Nol

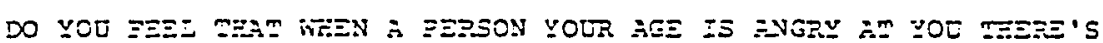
IIMTIE YOÜ CiN DO TO STOP EIM OR EEI? VEsi )

注: VIst ! : $: 01$

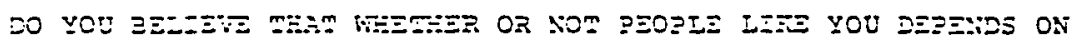
:ow You sic:? vasi,

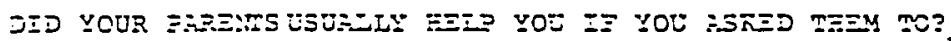
vas!) $\mathrm{x}: \mathrm{l}$

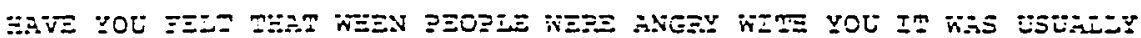

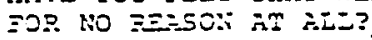
vasi, s:o6

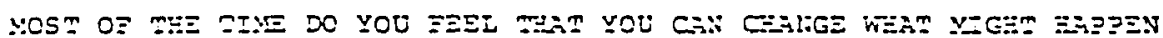
GOMORROW EY WHET VOU DO TODAY? vast $1 \mathrm{Nol}$

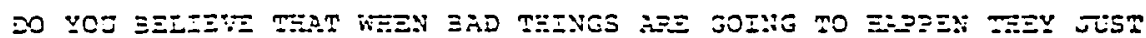

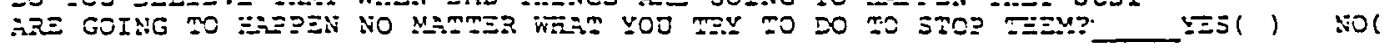

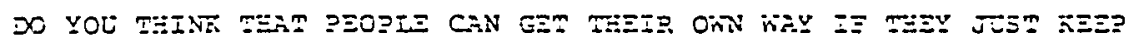
TEYI:S? yas( ) $: \because 01$

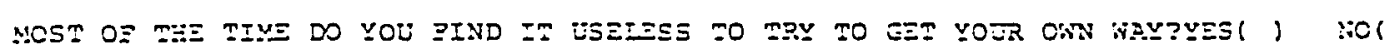

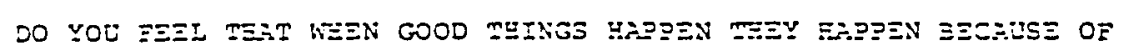
$\because=ב D$ NOR̈? Yas( ) : :ol D

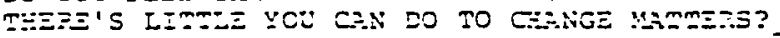
- $=35 i$, sio

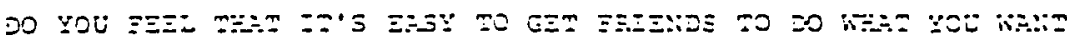
TES:Y TC? 
6

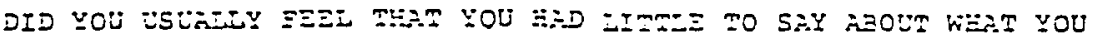

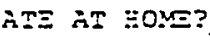
rasi) not

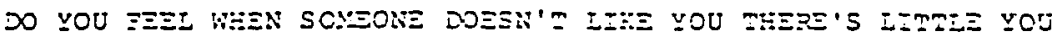
CiN DO ESOUT IT? YEsi , NOS

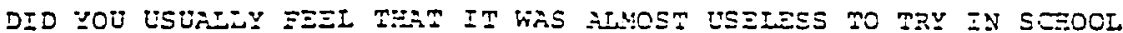

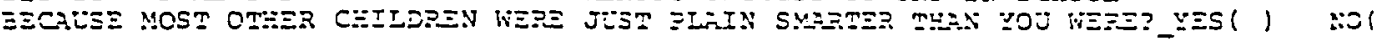

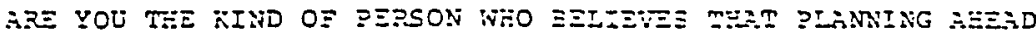

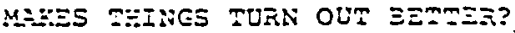
Yes(, soi

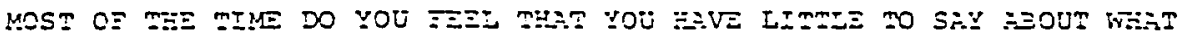

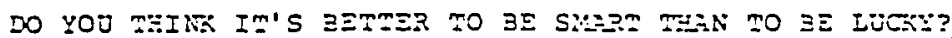
vasi, s:o : $\therefore \in \equiv$ $\Xi \Xi \because \pi=$ MiI $\equiv$

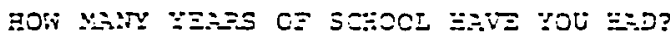

1. GIDDE SCECOE $(\Sigma-\Xi)$

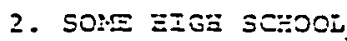

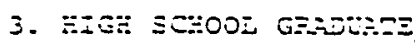

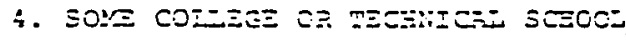

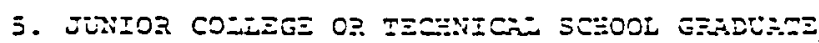

6. COIUEGE GRบDURTE

7. $C \div: \Xi z$

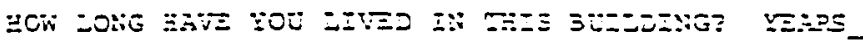

1:0:: $:: 5$

บอร, :

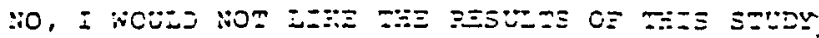

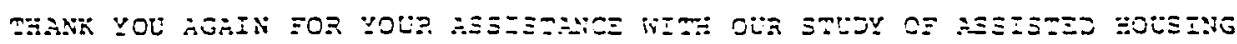
"MinG 


\section{APPENDIX D}




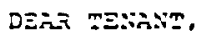

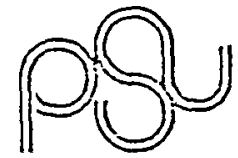

THES IS A FOLLON UP ON THE QUESTIONHniRE $n \equiv$ MiILED nO YOU

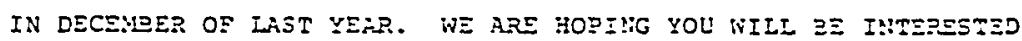

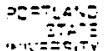

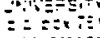

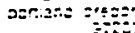
sasion and

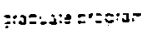
$\therefore \geq z:-i s e$

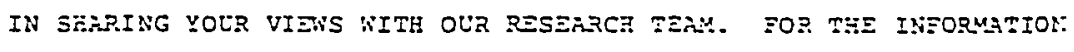

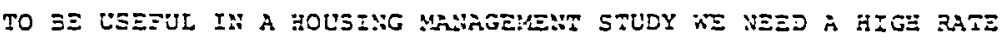

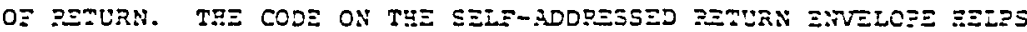

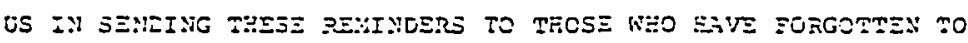
SETURN THE SURYEY.

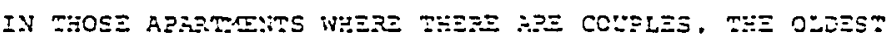

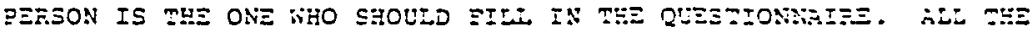

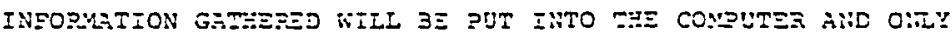

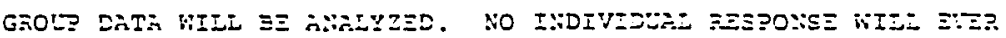

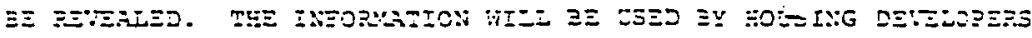

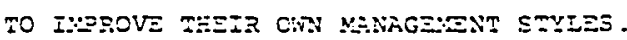

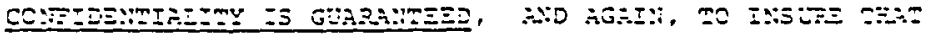

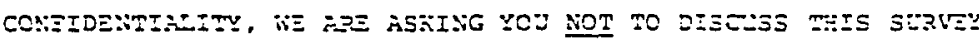

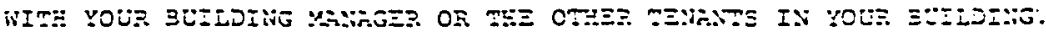

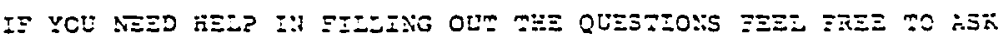

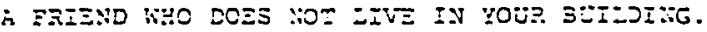

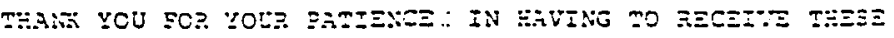

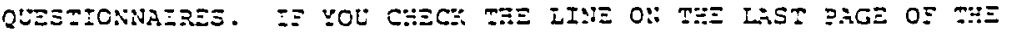

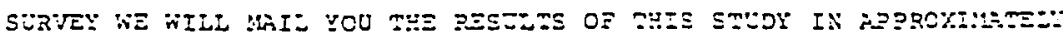
SIX mo EZG:2 MONTES.

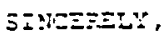

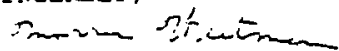

NOpgIS :

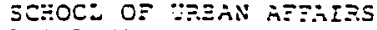

? 
APPENDIX E

$=+\ldots$ 

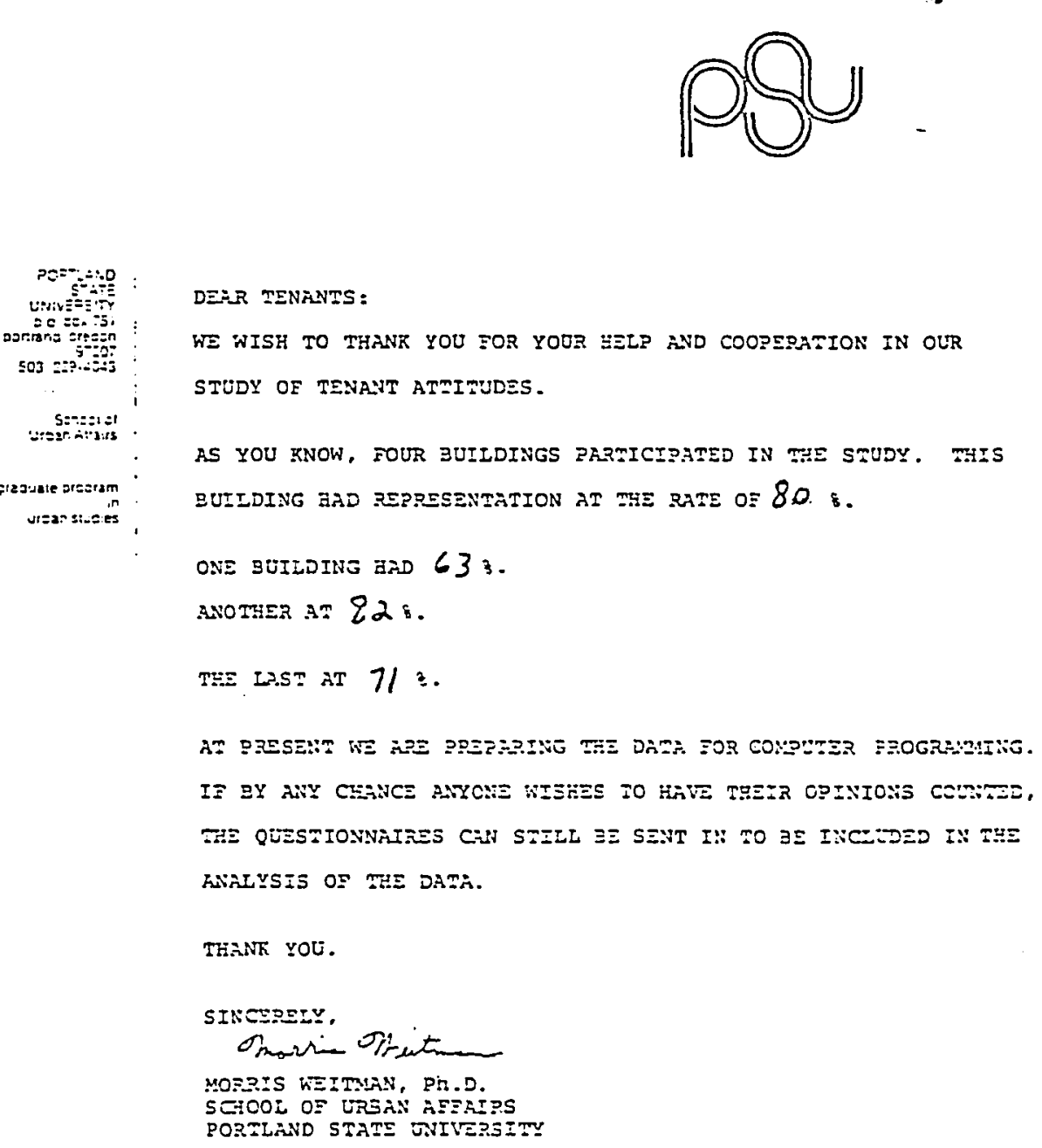
APPENDIX F 
FREQUENCIES OF NUMBER OF VALID RESPONSES ON LOCUS SCALE

\begin{tabular}{|c|c|c|c|}
\hline Code & Frequency & $\begin{array}{l}\text { Adjusted } \\
\text { Pct }\end{array}$ & $\begin{array}{c}\text { Cumulative } \\
\text { Pct }\end{array}$ \\
\hline 0 & 2 & 1 & 1 \\
\hline 1 & 2 & 1 & 2 \\
\hline 2 & 1 & 0 & 2 \\
\hline 3 & 1 & 0 & 3 \\
\hline 4 & $i$ & 0 & 3 \\
\hline 5 & 2 & 1 & 4 \\
\hline 6 & 3 & 1 & 5 \\
\hline 7 & 2 & 1 & 6 \\
\hline 8 & 1 & 0 & 6 \\
\hline 9 & 3 & 1 & 8 \\
\hline 11 & 1 & 0 & 8 \\
\hline 12 & 1 & 0 & 8 \\
\hline 14 & 2 & 1 & 9 \\
\hline 15 & 6 & 3 & 12 \\
\hline 16 & 1 & 0 & 12 \\
\hline 17 & 3 & 1 & 14 \\
\hline 18 & 1 & 0 & 14 \\
\hline 19 & $i$ & 0 & 14 \\
\hline 20 & 2 & 1 & 15 \\
\hline 21 & 3 & 1 & 16 \\
\hline 24 & 1 & 0 & 17 \\
\hline 25 & 1 & 0 & 17 \\
\hline 26 & 2 & 1 & 18 \\
\hline 27 & 1 & 0 & 19 \\
\hline 28 & 6 & 3 & 21 \\
\hline 29 & 5 & 2 & 23 \\
\hline 30 & 4 & 2 & 25 \\
\hline 31 & 5 & 2 & 27 \\
\hline 32 & 6 & 3 & 30 \\
\hline 33 & 6 & 3 & 32 \\
\hline 34 & 16 & 7 & 39 \\
\hline 35 & 19 & 8 & 47 \\
\hline 36 & 33 & 14 & 69 \\
\hline 37 & 93 & 39 & 100 \\
\hline
\end{tabular}


FREQUENCIES OF NUMBER OF VALID ANSWERS ON MANAGEMENT SCALE

\begin{tabular}{ccccc}
\hline Number & $\begin{array}{l}\text { Absolute } \\
\text { Frequency }\end{array}$ & $\begin{array}{l}\text { Relative } \\
\text { Frequency }\end{array}$ & $\begin{array}{l}\text { Adjusted } \\
\text { Frequency }\end{array}$ & Cumulative \\
\hline 0 & 2 & 0.8 & 0.8 & 0.8 \\
1 & 3 & 1.3 & 1.3 & 2.1 \\
2 & 6 & 2.6 & 2.5 & 4.6 \\
3 & 6 & 2.5 & 2.5 & 7.2 \\
4 & 6 & 2.5 & 2.5 & 9.7 \\
5 & 8 & 3.4 & 3.4 & 13.1 \\
6 & 12 & 5.1 & 5.1 & 18.1 \\
7 & 4 & 1.7 & 1.7 & 23.2 \\
8 & 8 & 3.4 & 3.4 & 35.9 \\
9 & 30 & 12.7 & 12.7 & 100.0 \\
10 & 152 & 64.1 & 64.1 & 100.0 \\
TOTAL & 237 & 100.0 & 100.0 & \\
\hline
\end{tabular}


FREQUENCIES OF NUMBER OF VALID RESPONSES ON VOLUNTEERS SCALE

\begin{tabular}{ccccc}
\hline Number & $\begin{array}{l}\text { Absolute } \\
\text { Frequency }\end{array}$ & $\begin{array}{l}\text { Relative } \\
\text { Frequency }\end{array}$ & $\begin{array}{l}\text { Adjusted } \\
\text { Frequency }\end{array}$ & Cumulative \\
\hline 0 & 26 & 11.0 & 11.0 & 11.0 \\
1 & 7 & 3.0 & 3.0 & 13.9 \\
2 & 10 & 4.2 & 4.2 & 18.1 \\
3 & 14 & 5.9 & 5.9 & 24.1 \\
4 & 25 & 10.5 & 10.5 & 34.6 \\
5 & 155 & 65.4 & 65.4 & 100.0 \\
TOTAL & 237 & 100.0 & 100.0 & \\
\hline
\end{tabular}


APPENDIX G 
TABLE 1

Analysis of Varlance - Varlable Education - By Varlable Bullding

\begin{tabular}{|c|c|c|c|c|c|}
\hline Source & $D . F$. & SS & MS & E Ratio & E Prob. \\
\hline $\begin{array}{l}\text { Between Groups } \\
\text { Within Groups } \\
\text { Total }\end{array}$ & $\begin{array}{r}3 \\
212 \\
215\end{array}$ & $\begin{array}{r}20.21 \\
438.00 \\
458.21\end{array}$ & $\begin{array}{l}6.73 \\
2.0660\end{array}$ & 3.262 & 0.0224 \\
\hline Group & Number & Mean & St. Dev. & Minimum & Maximum \\
\hline $\begin{array}{ll}\text { Bldg. } & A \\
\text { Bldg. } & B \\
\text { BIdg. C } \\
\text { Bldg. D }\end{array}$ & $\begin{array}{l}50 \\
34 \\
58 \\
74\end{array}$ & $\begin{array}{l}3.5800 \\
2.9412 \\
3.0517 \\
2.7703\end{array}$ & $\begin{array}{l}1.5791 \\
1.4342 \\
1.3432 \\
1.4098\end{array}$ & $\begin{array}{l}1.000 \\
1.000 \\
1.000 \\
1.000\end{array}$ & $\begin{array}{l}6.0000 \\
6.0000 \\
6.0000 \\
6.0000\end{array}$ \\
\hline \multicolumn{6}{|c|}{ Analysis of Covarlance - Sat. W/Mng. - By Bullding - With Education } \\
\hline Source & D.F. & SS & MS & E Ratio & Signif. of $E$ \\
\hline $\begin{array}{l}\text { Covarlate } \\
\text { Education }\end{array}$ & 1 & 0.807 & .807 & 2.288 & 0.133 \\
\hline \multicolumn{6}{|c|}{ Analysis of Covarlance - Volunteerism - By Bullding - With Education } \\
\hline Sour ce & D.F. & SS & MS & E Ratio & signif. of $E$ \\
\hline $\begin{array}{l}\text { Covarlate } \\
\text { Education }\end{array}$ & 1 & 0.164 & .164 & 0.287 & 0.593 \\
\hline
\end{tabular}


TABLE 2

Analysis of Varlance - Varlable How Long (Months) - By Varlable Bullding

\begin{tabular}{lrrrrr}
\hline \multicolumn{1}{c}{ Source } & D.F. & \multicolumn{1}{c}{ SS } & MS & E Ratio & E Prob. \\
\hline Between Groups & 3 & 20907.98 & 6969.3278 & 47.695 & 0. \\
Within Groups & 223 & 32585.69 & 146.1242 & & \\
Total & 226 & 53493.6748 & & & \\
\hline
\end{tabular}

\begin{tabular}{lrrrrr}
\hline Group & Number & Mean & St. Dev. & Minimum & Maximum \\
\hline BIdg. A & 54 & 12.5556 & 3.8835 & 2.0000 & 24.0000 \\
BIdg. B & 34 & 41.0203 & 25.2483 & 0.2300 & 84.0000 \\
BIdg. C & 64 & 15.3556 & 8.7561 & 1.3800 & 43.0000 \\
BIdg. D & 75 & 25.5556 & 8.9439 & 1.0000 & 45.0000
\end{tabular}

\begin{tabular}{lccccc}
\multicolumn{4}{c}{ Analysis of Covarlance - Sat. W/Mng. - By Bullding - With How Long } \\
\hline Source & D.F. & SS & MS & E Ratio Signif. of E \\
\hline $\begin{array}{l}\text { Covariate Long } \\
\text { Ww L }\end{array}$ & 1 & 0.906 & 0.906 & 2.449 & 0.120
\end{tabular}

Analysis of Covarlance - Volunteerism - By Bullding - With How Long

\begin{tabular}{lccccc}
\hline Source & D.F. & SS & MS & E Ratio Signif. of E \\
\hline $\begin{array}{l}\text { Covariate } \\
\text { How Long }\end{array}$ & 1 & 0.796 & 0.796 & 1.386 & 0.241
\end{tabular}

\begin{tabular}{cccccc}
\multicolumn{5}{c}{ Analysis of Covarlance - Manage - Education - How Long - Building } \\
\hline Source of Variation & D.F. & SS & MS & E Ratlo Signif. of E \\
\hline -way Interactions & 15 & 4.600 & 0.307 & 0.913 & 0.55
\end{tabular}

\begin{tabular}{llllll} 
Analysis of Covariance - Volunteer Ism - Education - How Long - Bullding \\
\hline Source of Varlation & D.F. & SS & MS & E Ratlo Signif. of E \\
\hline 2-way Interactions & 15 & 9.718 & 0.648 & 1.235 & 0.259
\end{tabular}


APPENDIX H 
The owners and developers of Bullding $A$ were unusual In their concern for their upcoming older tenants. They were willing to change their orlginal management plan to accommodate this study's clted guldelines, even to the point of allowing interlor structural changes. In the final analysis, the owners and operators were satisfled with the results. 


\section{h Brim \& Associahes, inc. \\ PSchiavement Through}

October 22, 1982

Thelma Lofquist

$1019 \mathrm{~s}$. W. loth Avenue

Portland, OR 97205-2406

RE: The First 365 Days

Dear Thelma:

Congratulations on living through a new project rent-up period completing the first 365 days. The evaluation report which you and Linda have discussed reflects all of the positive assets that you have brought to - You have done an outstanding job of developing a "sense of community" among the. residents at Chaucer court and you have been especially successiul in attracting highquaiity tenants. I am positive that even though we will face increased competition in the years to come, - will prosper due to the positive attitude which has developed in our residents as a result of your leadership.

Iinda has commented that your growing understanding of plant design and function could be of assistance in our other developments. I believe this is true and I look forward to having you work with our architects and project managers on new projects.

Thelma, congratulations again. You have done a very good job at much as $w \geq$ have.

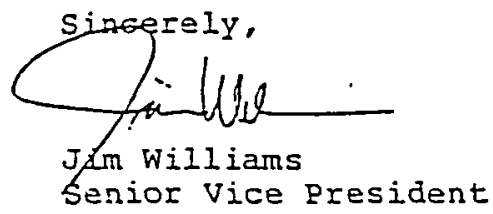

JW/ Imd 


\section{G Srim \& Assariaies, Inc. \\ $\sim \longrightarrow$ \\ Achiavement Through Ezcallenca}

June 27,1983

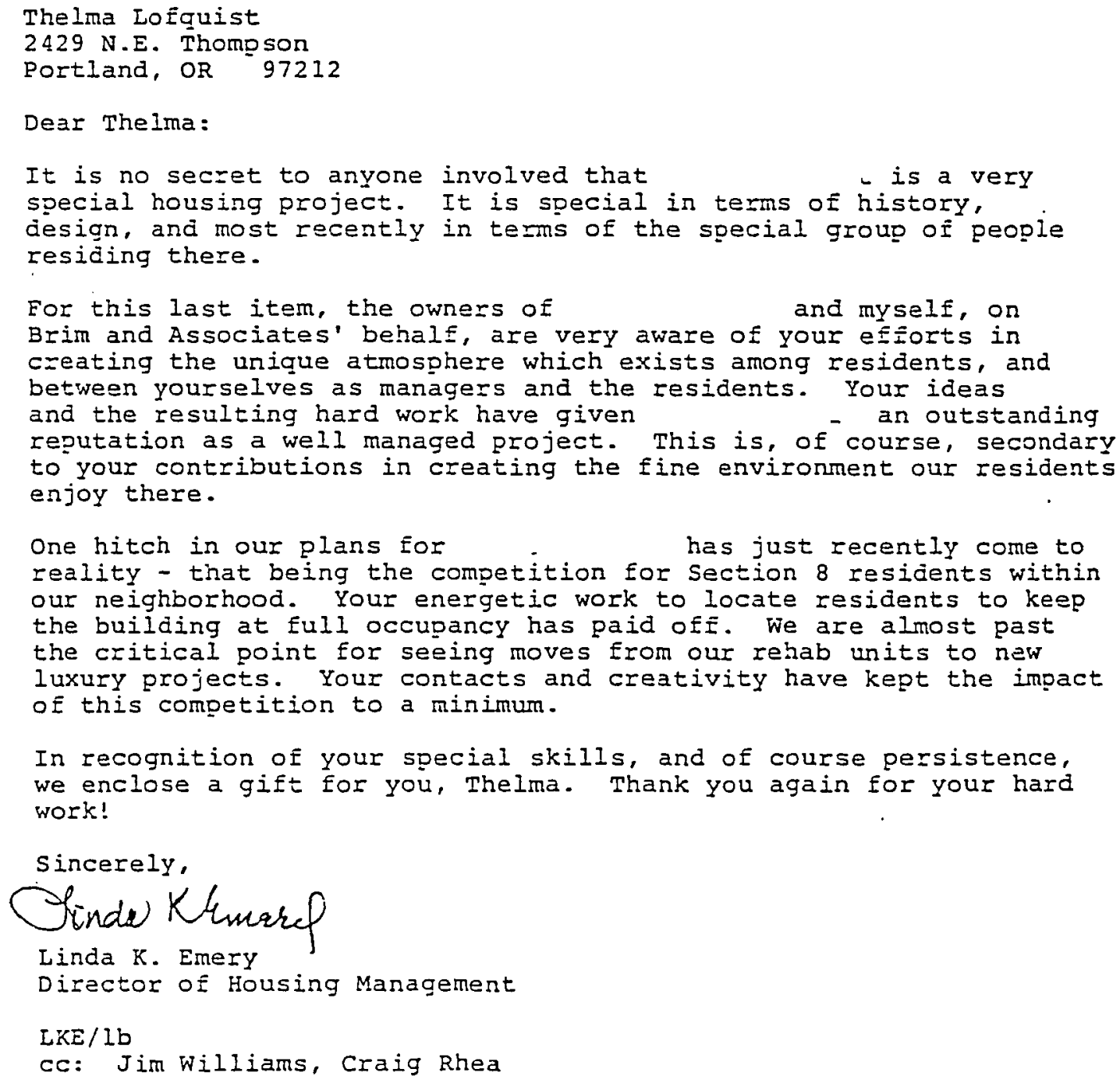


Dear Thelma:

I wanted to take this opportunity to express my gratitude for the courtesies you have extended to my sister, Charlene 1983.

In particular, I wanted to tell you how well pleased I was to find an apartment complex that was managed as well as and, as time goes on, I am sure it will

continue. Three things have impressed me; the first was the cleanliness of the entire building and the general maintenance. If anything needs attention, it gets taken care of soon.

The second thing that really impressed me was the quiet atmosphere which always prevails. In an apartment house with so many tenants, it is really amazing that the main lobby is always so quiet and peaceful.

The tinird and most important impression I have is the caliber of people in both the management and tenants. Yourself and Grant and Lynn Stephens have extended yourselves in order to make my sister feel comfortable in her new home. To make her feel welcome, you have done things which you did not really have to do -- but things for which I an thankful and will not forget.

The tenants also have been instrumental in helping Charlene adjust more readily to her new surroundings. She now feels more secure than she has in many years, and says she likes "her new home".

The bottom line is that Charlene can live and is adjusting. more readily than I could have ever believed possible to a better quality of life. Before she moved to. she was close to being a recluse. Now her social life is expanding little by little, and for that I am particularly thankful. It takes "special" people to make aII that inprovement come about and, as manager, you set the tone -- you have done an excellent job!

I am confident that if I was trying to learn how to be an apartment manager, I would want you as my teacher -- and I would want Mr. and Mrs. Stephens right there to help me too! You are all great.

From both of us, thank you again, and keep up the excelient job.

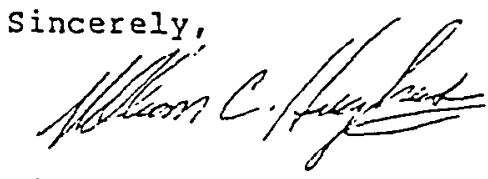

William C. Hughes 